\title{
Antecedents of Entrepreneurial Intention among Young People: Model and Regional Evidence
}

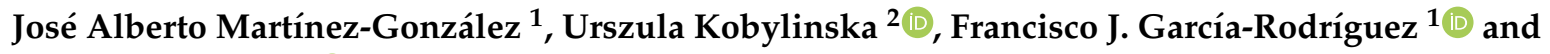 \\ Lukasz Nazarko $2, *$ (D) \\ 1 Department of Business Management and Economic History, Faculty of Economics, Business and Tourism, \\ University of La Laguna, 38200 Tenerife, Spain; jmartine@ull.edu.es (J.A.M.-G.); \\ fgarciar@ull.edu.es (F.J.G.-R.) \\ 2 Faculty of Engineering Management, Bialystok University of Technology, 15-351 Bialystok, Poland; \\ u.kobylinska@pb.edu.pl \\ * Correspondence: 1.nazarko@pb.edu.pl; Tel.: +48-85-7469802
}

Received: 15 October 2019; Accepted: 3 December 2019; Published: 7 December 2019

\begin{abstract}
Entrepreneurial intentions determine to a large extent the entrepreneurial behavior; therefore, the study of those intentions and the factors that influence them constitute a valid research area. The purpose of this regional comparative study was to design a new causal model of the formation of the entrepreneurial intention among young adults in Spain and Poland. Using the Structural Equation Modeling (PLS) methodology, the results show that subjective variables (beliefs, social norms, values) initiate the chain of effects that influence the action variables (motivation, self-efficacy, intention). Attitude is the nexus variable between both groups of variables. It is verified that there are no significant differences in the responses to the items or in the causal relationships of the model between both countries. This confirms the relevance of a homogenizing generational approach at a global level that allows the application of policies to promote the entrepreneurial intention for the entire segment. The proposed model takes into account and complements the previous designs, and is practical because it can be used at different levels of the education sector and by institutions promoting entrepreneurship and sustainability.
\end{abstract}

Keywords: entrepreneurial intention; attitude; social norm; subjective personal variables; motivation; beliefs; values

\section{Introduction}

Entrepreneurship is a phenomenon that is essential to economic growth and sustainable development of the countries, as well as to the creation of employment and prevention of economic crises [1-3]. At the individual level, the creation of companies has contributed enormously to satisfying the need for achievement of individuals who possess creative competencies and a propensity to risk $[4,5]$. However, on many occasions and for many reasons, the intentions of some entrepreneurs do not materialize in real projects, and the journey of entrepreneurship does not come to fruition $[6,7]$. For these reasons, researchers in this field make efforts to identify and strengthen the factors on which the venture depends $[8,9]$.

Special interest exists in the literature to improve the degree of knowledge of the variables that favor entrepreneurship in a regional context [10-12]. The phenomenon of globalization and the development of ICT have accentuated it, as they make entrepreneurship an international phenomenon, questioning the influence of regional and national frameworks [13-15]. There are two main lines of research about the factors that favor entrepreneurship [14,16]. The contextual approach assumes that environmental factors (e.g., education, culture, access to financial resources) are the most influential 
elements in the process of creating a company [14,17]. Entrepreneurs cannot innovate in isolation, they are influenced by, and dependent on, the institutional context in which they operate [18-20]. The institutional context consists of normative, regulative and cultural-cognitive institutions [21]. Regulative institutions are formal rules and laws. Normative institutions include social obligations and expectations, such as norms and values.

In the approach of human capital, the entrepreneur becomes the key element in the undertaking [22,23]. In the second approach, the works have focused on identifying the main attributes of the entrepreneur (e.g., values, self-efficacy, motivation), generally analyzed through their perceptions [24,25]. The focus of human capital predominates in the literature, and therefore, regional differences in entrepreneurial behavior tend to be explained to a greater extent by linking them to the personal factors of entrepreneurship [26]. In this approach, the role of contextual variables, which are more stable over time, consists in influencing the configuration of the personal factors of entrepreneurship [27]. Among the attributes of the entrepreneur, the entrepreneurial intention has acquired particular relevance in the literature. This is because it is the variable that best predicts entrepreneurial behavior [28,29].

There is also a need to study the entrepreneurial intention in a regional context in different population segments, since numerous sociological studies show the increasing homogenization of cognitive, affective-relational and behavioral patterns derived from the globalization process [30]. This is especially relevant for younger generations, such as the so-called Generation Y or Millennials (young people born approximately betwen 1980 and 2000). Authors such as Nabi, Holden and Walmsley [31] suggest their quantitative importance and relevance in the generational change in the current population of entrepreneurs. Particularly high is the interest in knowing the entrepreneurial intention in the case of university students because they are a good representation of that generation [32,33]. It is now generally accepted that education is vital in the creation of entrepreneurial individuals and in turn an entrepreneurial community $[34,35]$. Universities are the pillars of knowledge, providing students with a high level of information and skills needed to develop entrepreneurial tendencies [36]. Additionally, in the 2018 Global Student Entrepreneurship report (www.guesssurvey.org) special emphasis is placed on the crucial impact of student entrepreneurship, both economically and socially, making the study of entrepreneurial intention an even more relevant topic. At the university stage, students define their future perspectives in the short and medium terms, with entrepreneurship becoming a job option that is increasingly valued by them [37]. Likewise, it has been verified that education favors the learning of entrepreneurship and allows to distinguish the people who become entrepreneurs from those who do not. At the same time, it has been posited that inadequate education may hinder the entrepreneurial intention among students [38-40].

Descriptive studies have been developed on the personal factors on which entrepreneurship depends at a regional level, as is the case of the studies developed by the Global Entrepreneurship Monitor (GEM) (www.gemconsortium.org) [41]. GEM data provide insights into a population of individuals engaged in self-employment; however, they are limited in terms of the number of observations and variables included in the survey [42]. Likewise, causal models including personal variables and to a lesser extent, contextual variable have been developed, with the intention of identifying the dependent variable most used in these models [43]. The causal models have been fundamentally based on the proposal of Shapero and Sokol [44] of the entrepreneurial event and on the planned behavior model of Ajzen $[29,45,46]$. These models have received some criticism, and other authors have emphasized the importance of further clarifying the role played by certain personal variables. The need to introduce new subjective personal variables associated with action, such as beliefs and motivation, has also been highlighted [47].

The article contributes important insights to this Special Issue, taking into account that youth entrepreneurship could influence sustainable and economic development of regions. The article defines the factors that influence the entrepreneurial intention in the case of young people. Policymakers can use the findings of this research to establish policies to improve the conditions in their regional ecosystems for sustainable entrepreneurship. Hence, the findings can help them achieve their goal 
of transitioning to a more sustainable local economy. Specifically, the results show that there is a potential for action in this field to improve the influence on the entrepreneurial intention in the teaching and learning process. To address the concerns and suggestions found in the literature and to enrich this special issue of Sustainability Journal this study aims at causal analysis in a regional comparative framework of personal variables that influence the entrepreneurial intention of the young people of Spain and Poland. Both countries are members of the EU and present sufficient similarities and differences to verify whether a homogenizing generational approach has greater weight on the entrepreneurial intention, using exclusively personal variables, than the possible differences in these variables that could derive from contextual aspects characteristic of each country. One of the articles on the expectations of Generation Y (students from Poland and Spain) regarding the labor market concluded that, despite the differences, (due to history and lifestyle) Millennials from both countries have a lot in common: They put bonds with loved ones among the priorities, their field of study is determined by their own interests and they expect a good atmosphere, decent earnings and work-life balance from their future workplace [48].

The proposed causal model, which takes into account previous reference models, is new and complete because of the type and number of personal variables and relationships it includes. Unlike the GUESS reports, this study includes variables and causal relationships that these reports do not contemplate. This model includes only subjective personal variables (e.g., beliefs, social norm) and personal action variables (e.g., motivation, self-efficacy). The inclusion of subjective variables, and social and conditioned nature, allows to determine to what extent entrepreneurship is a conscious or conditioned process.

If it is confirmed that there are no significant differences between the models of both countries, or in the responses to the items, the existence of a homogenizing generational approach could be revealed. In this way, measures to promote entrepreneurship in different regional contexts could be adopted at an educational and institutional level and for the entire segment. However, not all variables of the proposed causal model are equally manageable by educational institutions. In order to carry out the comparisons between both countries, novel statistical techniques are introduced in this study, such as the discriminant analysis and the multigroup AMS analysis in a PLS-SEM context [49], the permutation test [50], and the analysis of the invariance of measure (MICOM) [51].

The article is structured in the following way. Analysis of the entrepreneurial intention is addressed first. Next, the model and the hypotheses associated with it are presented, to subsequently present the results as well as their discussion.,. The paper ends with the conclusions and implications of the study, followed by the indication of the possible future research directions.

\section{Theoretical Development}

The intention is conceived as a conscious, deliberate and planned mental state that precedes the action and allows direct attention to certain behaviors, such as the behavior of creating a company $[52,53]$. The intention has also been called propensity, motivation and intentional decision [38]. In the context of entrepreneurship, the entrepreneurial intention is defined as the attempt to create new businesses, including self-employment or the expansion of an existing business by an individual, a team of individuals or an already established business $[54,55]$.

Entrepreneurial intention (EI) is a state of mind [56] leading an individual to choose self-employment over working for another. Various studies, such as that of Turton and Herrington [57], Hornsby et al. [58] and Guerrero and Peña-Legazkue [59] discuss the positive relationship between EI and entrepreneurial activity, as well as its subsequent connection with economic development. The growing interest in the study of entrepreneurial intention is related to several factors. In the first place, the intention has a high correlation with the behavior of creating a company; this correlation being in some cases higher than 0.90 and 0.96 [6,60]. Moreover, the intention allows us to explain a high percentage of the variance of the behavior of entrepreneurship, and it is the variable that most accurately predicts entrepreneurial behavior [61]. In the educational context, some authors have also found a 
positive and significant causal relationship between intention and entrepreneurial behavior $[60,62,63]$. On the other hand, the intention is a measure of the will and effort that the entrepreneur is ready to make to establish a company $[37,64,65]$.

Essentially, there have been three models that serve as a guide to understand the development of the entrepreneurial intention: The Bird model [66] to implement business ideas, the entrepreneurial event model (EEM) of Shapero and Sokol [44] about the business event, and Ajzen's theory of the planned behavior [45] (TPB). EEM and TPB are "the two most extensively tested competing theories that have been used to explain entrepreneurial intention" [67,68]. In the Shapero and Sokol model [44] the entrepreneurial intention is formed based on perceived desirability, perceived viability and the propensity to act [69]. Theory of planned action, in turn, maintains that the intention to establish an enterprise is dependent on the three variables: Attitude toward behavior, perceived behavioral control and subjective norm. In this model, attitude is the initial variable of the chain of direct and indirect effects that leads to intention [70,71]. The attitude in this model corresponds to the perceived desirability included in the former model, and behavioral control is a form of perceived viability, considered in the Shapero and Sokol model [44]. Ajzen adds the subjective norm in the second model, which also influences the entrepreneurial intention [72-74]. Intention-based models are implemented successfully in social psychology, marketing and management, and prior research revealed very interesting empirical conclusions. All the determinants indicated in the TPB and EEM models showed that the variables included in the two models have a positive and direct effect on entrepreneurial intentions among young people [65].

Although both models have been empirically tested and offer satisfactory predictions of the entrepreneurial intention, the use of the theory of planned behavior predominates in the literature, due to its high predictive power [69]. Due to the predictive power of intention over entrepreneurial behavior, in the majority of the designed models, the entrepreneurial intention has been used as a dependent variable $[69,75]$.

In addition to the variables mentioned in the causal models of reference, other authors have focused on other personal variables than those mentioned above, highlighting demographic variables, life history, work experience and gender [68,76,77]. Psychological variables have also been taken into account, as is the case of motivation or personality traits (e.g., commitment, self-esteem, safety, extroversion) $[62,78,79]$. In any case, the most influential articles regarding entrepreneurial intention can be classified into five groups. The first category includes articles that address theoretical and methodological issues that test the central models [72]. The second category includes articles focused on variables, such as gender [80], family roles [81], social capital [82], and personality traits [83]. The third group of studies addresses the role of education in the context of entrepreneurship [84]. The documents that are classified in the fourth category, the least numerous, focus on the role of context and institutions, covering samples from several countries [85]. The last group of articles analyzes the links between intention and behavior, confirming the high predictive potential of intention on entrepreneurial behavior [86,87].

Despite the conducted studies and the obtained findings, there is a number of reasons that suggest the need to deepen the study of entrepreneurial intention, particularly in the case of young people because there is consensus in the literature regarding personal factors that influence their entrepreneurial intention, as well as divergence from other factors in different contexts (e.g., marketing) [88,89]. In the first place, some researchers consider it necessary to enrich the theoretical framework on the entrepreneurial intention $[8,61]$. At the empirical level, the emphasis is placed first on the enrichment of the models designed for study $[90,91]$. In this sense, some authors propose that new variables and relationships are introduced into the models. This is the case of commitment [92], and also of cognitive scripts, schemas and mental maps, which play a relevant role in the formation of the entrepreneurial intention through automatic processing [92].

At the contextual level, some researchers propose to deepen the understanding of the influence of institutions [93] and culture [94] on entrepreneurial intention. Likewise, it would be of great interest 
to investigate further the entrepreneurial intention in the wide range of business scenarios, such as social entrepreneurship [95], family entrepreneurship [96], and entrepreneurship in the academic context $[61,97]$. In the latter case, it would be useful to explore the possible causal link between some educational variables (e.g., selection of participants, course contents, pedagogical methods) and certain factors that influence the intention and/or behavior (e.g., attitudes, values, abilities) [78,98]. Finally, some researchers suggest the need to carry out a greater number of comparative studies of the entrepreneurial intention at the regional level [52,94,99], and in the context of sustainable entrepreneurship [99,100].

Particularly noteworthy is the recent trend that emphasizes the role of certain subjective variables in the formation of entrepreneurial intention. This is the case of the social norm, or of the process of identity and social self-categorization of the entrepreneur [101]. Within this stream, it is considered that, although companies are created voluntarily and intentionally $[28,43]$, it is the socialization that creates ground for unconscious internalization of attitudes and values that, ultimately, will make the entrepreneur create a company [76,77]. This raises the need to determine to what extent the entrepreneurial intention and entrepreneurship are voluntary processes and conscious or conditioned and unconscious. This study is framed in this stream of thought because it analyzes the causal influence of certain subjective variables on certain personal variables associated with the action, which in turn influence the intention and behavior of undertaking.

\section{Model and Hypothesis}

During their development process, students adopt a series of beliefs about various aspect of life, including entrepreneurship and the role that education plays in its promotion [102]. It can be affirmed in this sense that socio-culture influences entrepreneurship because it takes place within a social context and a network of relationships that facilitate such beliefs, as well as the infinity of aspects, such as the detection of opportunities, the acquisition of resources or the legitimacy of the company $[69,103]$. Beliefs are accepted and internalized by specific individuals or groups, usually unconsciously, and carry with them the obligation to perform behaviors to achieve compliance. In this way, the beliefs reflect a commitment and intentions of ideal behavior according to what a person feels should be done $[25,104,105]$. It can be affirmed that beliefs are a measure of expectations about behavior and the corresponding motivation to fulfill them [106-108].

In the context of the theory of planned behavior beliefs are important because they influence the social or subjective norm, which is defined as the perception of the subject about how the people close to him/her (e.g., family, friends) would accept his/her intentions, decisions and behavior [71]. Therefore, the social norm also possesses an unconscious content and is derived from beliefs and is related to them through a continuous process of causality $[106,109,110]$. For these reasons, some authors suggest that beliefs should be included in models that examine behavioral intentions, in which this type of prior sociocultural precursors are often ignored [111,112]. Taking the above into account, the first hypothesis states that:

Hypothesis 1 (H1). Beliefs about the role of education in the promotion of entrepreneurship have a direct and positive influence on the social norm.

The values are directly related to the extent to which a person has an opinion or predisposition, positive or negative, towards an object or behavior, in this case, the behavior of creating a company $[70,113]$. Moreover, values constitute criteria of action that are at the origin of any behavior, have high stability and are formed during the process of socialization. Therefore, just as with beliefs, values are also largely determined unconsciously and conditioned by the prevailing shared culture in society $[114,115]$. In any case, in most explanatory models of the formation of entrepreneurial intention values are found in the initial phases of the chain of direct and indirect effects that culminate in the intention and behavior of undertaking [116,117]. 
It is a proven fact that the social norm influences values [118]. It is due to the influence exercised by the social norm that individuals adopt certain values when they perceive that these values and associated behaviors are expected and approved by significant and influential agents [119,120]. Additionally, in a generational context, it is assumed that young people share values and are easily influenced by other subjects, due to the pressure of conformity [121]. Particularly in the case of young people, there is a tendency to make efforts to imitate others [122]. However, the role of the subjective norm in entrepreneurship has not been sufficiently clarified [123]. Taking the above into account, the following hypothesis dictates that:

Hypothesis 2 (H2). The social norm has a direct and positive influence on values related to entrepreneurship.

In the context of entrepreneurship, an attitude refers to the predisposition of a person towards the behavior of creating a company $[70,113]$. In explanatory models of the intention-to-undertake attitude formation, it is also found in the initial phases of the chain of direct and indirect effects that culminate in the intention and behavior of undertaking [116,124]. Regarding the antecedents of the attitude, for decades social scientists have studied the values to understand the attitudes of the subjects in different areas, as is the case of entrepreneurship [125-127], having verified that the values justify and explain the attitudes of the individuals $[128,129]$. This causal relationship is otherwise reasonable if one takes into account that the attitude is closer to the behavior, and that the values are part of the subject's personal philosophy, which in turn is influenced by the social norm and by the beliefs $[70,113]$. In this way, the attitude is also formed in the process of socialization and has an unconscious and conditioned content. Additionally, the attitude could be considered a variable that serves as a link between the values and other variables more linked to the action, such as motivation, self-efficacy and intention [126]. Taking the above into account, the following hypothesis states that:

Hypothesis 3 (H3). Values directly and positively influence the attitude toward entrepreneurship.

It has been found that attitude plays a fundamental activating role in the formation of the entrepreneurial intention, usually indirectly $[44,45,70]$. Many authors consider that efforts should be made to incorporate new personal variables into the models that serve as linkages between the attitude and the entrepreneurial intention, such as the case of motivation $[101,116]$. In this sense, there is a particular interest in the study of motivation to undertake, due to its high relevance in the process of creating a company $[29,130,131]$. The influence of attitude on motivation has already been verified by some authors in different fields, who have found that the favorable attitude towards a behavior constitutes the germ of the motivation towards such behavior [131]. Therefore, the favorable predisposition toward entrepreneurship, that is, attitude, favors the generation of motives and desires towards the creation of a company [132]. Additionally, taking into account that the motivational system of the subject is generated in a context of socialization and a specific cultural framework, it is understandable that the values, the social norm and the attitude have a causal relationship, direct or indirect, with motivation, such and as some authors suggest $[133,134]$. Based on the above, the following hypothesis is established as follows:

Hypothesis 4 (H4). The attitude has a direct and positive influence on the motivation to undertake entrepreneurial activity.

There are several reasons that motivate the entrepreneur to create a company, and all of them are classifiable in internal or external $[135,136]$. Among the internal factors or of necessity, the desire for achievement and the desire for independence and autonomy stand out, and among the external or opportunity motives, it is worth mentioning the desire to increase income or obtain social status $[8,132,137]$. Regarding the consequences of motivation, it has been found that internal and external motivation increases the alertness of entrepreneurs to new opportunities, activates creative problem solving, 
improves cognitive flexibility, leads entrepreneurs to devote considerable effort and it influences the entrepreneurial intention $[130,131]$.

The consequences of motivation seem to be mediated by self-efficacy, an essential attribute of the potential entrepreneur that refers to the extent to which a person believes that he or she can organize and execute actions effectively to produce certain achievements [138-140]. Taking into account that self-efficacy influences the amount of effort and perseverance in the face of the difficulties and challenges faced by the entrepreneur, it seems reasonable to think that the motivated person feels more self-effective than the less motivated person $[48,141]$. Based on the foregoing, the following hypotheses suggest that:

Hypothesis 5 (H5). Motivation directly and positively influences the self-efficacy to undertake entrepreneurial activity.

Self-efficacy influences the setting of goals, expectations of results [8], and the entrepreneurial intention, which is a measure of the will and effort that the entrepreneur is willing to make to create the company [142-144]. This relationship between self-efficacy and intention is particularly important because the intention is the variable that best predicts entrepreneurial behavior [61].

On the contrary with people who have a high self-efficacy, people with low self-efficacy believe that they cannot be successful, and therefore, have less intention and less likely to make an effort, being able to consider that challenging tasks are threats that should be avoided [139]. These processes seem to be due to the fact that self-efficacy is related to levels of perceived personal competence, which in turn are linked to the perception of control and the possibility of coping with processes that assume a certain risk, as is the case of entrepreneurship [120,145]. In view of the foregoing, it is stated that:

Hypothesis 6 (H6). Self-efficacy influences positively and directly the entrepreneurial intention.

Taking into account the hypotheses, the following a model of the relations between personal factors and entrepreneurial intention is proposed (Figure 1). It includes variables and partial relationships that have been verified in other studies. Additionally, in this and other studies, the subjective drivers influence the variables that lead to the intention and action, mediated by attitude.

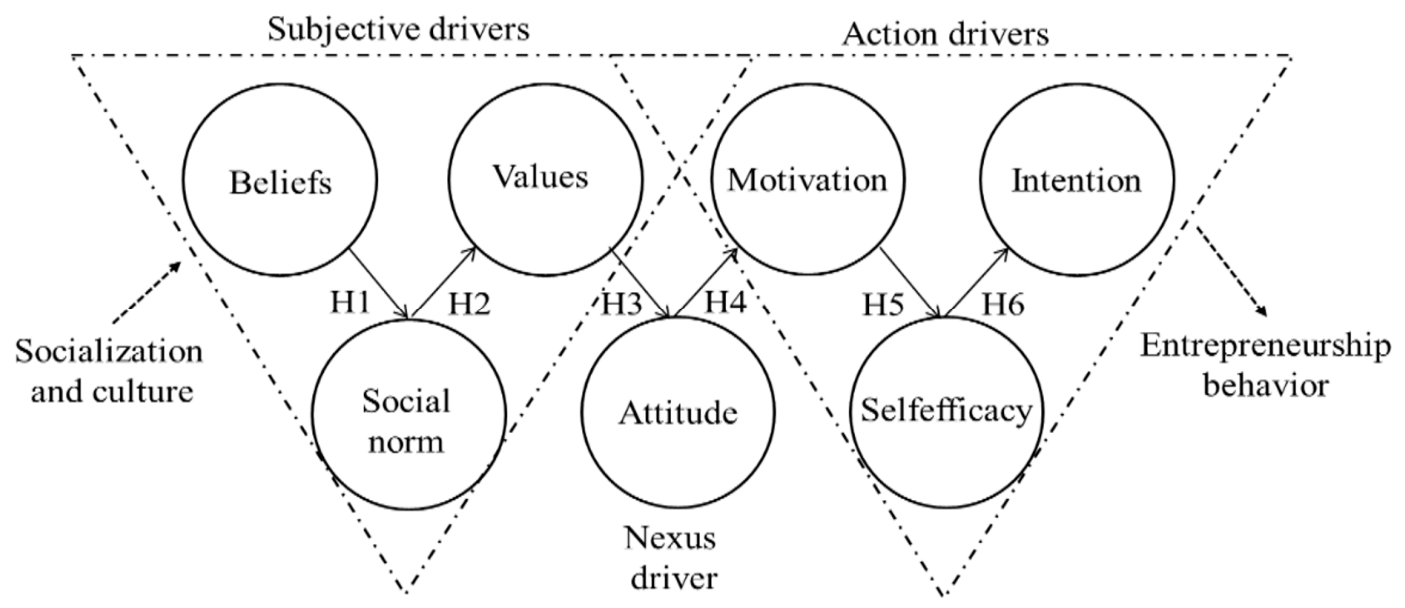

Figure 1. Proposed model of the relations between personal factors and entrepreneurial intention (Based on the review of the literature mentioned in the development of the hypotheses).

Regional differences in entrepreneurial behavior tend to be explained to a greater extent by personal factors of the entrepreneur than by contextual factors [26]. Therefore, it is personal variables that mainly lead to variations in the quantity and quality of entrepreneurship at the regional level [146]. Additionally, some researchers have confirmed the greater homogenizing weight inherent in a generational approach 
to the differentiating effect of the personal variables associated with each country [30]. Therefore, taking into account the foregoing and considering that young people of generation $Y$ share perceptions, values and attitudes at a global level [147], the following hypothesis states that:

Hypothesis 7 (H7). There are no significant differences between Poland and Spain in the causal relationships of the proposed model.

\section{Research Method}

\subsection{Context}

This study has been carried out in a public university in Poland and another in Spain, two countries that have in common their belonging to the EU, but that have a different socio-cultural, political and economic trajectory. From economical, institutional and cultural perspectives, having a reference point in data from another country is cognitively beneficial and allows for more adequate and in-depth judgments. Poland and Spain form a legitimate reference point in many respects [148]. Both countries belong to large European economies. They are diverse geographically and demographically. They share a similar story of the transition from closed, centralized economies to market-driven capitalist order [149]. Similarities are also noticeable in particular sectors of the economy and in the role of micro, macro and medium-sized enterprises which contribute significantly to the employment and added value in both economies. The reason for comparing Poland and Spain also derives from cultural and institutional conditions favoring entrepreneurial attitudes, development of social capital, and ultimately affecting the shape and dynamics of economic processes [148]. In addition, in the comparative research of generation $Y$ expectations regarding the future workplace carried out on a small group of students from Poland and Spain, it turned out that the priorities in two countries are very similar: Both Polish and Spanish students expect a good atmosphere at work, high earnings and work-life balance [48]. In Spain, entrepreneurial activity has remained stable, since the economic recession, but the economic and labor impact of established companies has increased markedly (https://www.gemconsortium.org/report). The 2019 GEM Report of Spain highlights that the entrepreneurial activity in Spain is strongly influenced by the recovery phase of the economic cycle, and the growth of the propensity to be an entrepreneur by the Spanish population. The latest report highlights the increase in the perception of opportunities in the environment $(+8 \%)$, as well as entrepreneurship by opportunity versus the need $(+3 \%$ vs. $-20.3 \%)$. Also highlighted in this report is an increase in the perception of entrepreneurship abilities $(+8.2 \%)$, the decrease in fear of failure $(-1.1 \%)$ and a decrease in the rate of entrepreneurship (ASD) among young people aged 18-24 years of 1.6\% between 2017 and 2018. In Poland, the Polish government carried out several legislative actions in 2018 to promote entrepreneurship, and in that same year, the social perception regarding the creation of new companies improved. Three-fourths of adults in Poland stated that it is easy to start a business in their country. However, the percentage of new entrepreneurs has decreased, due to the excellent situation of their labor market. According to the data of the report prepared by the GEM (https://www.gemconsortium.org/report), in 2018 Poland was characterized by a somewhat lower $(-0.35 \%)$ perception of the opportunities generated by entrepreneurship, a lower fear of failure $(-3.29 \%)$, a better perception of social status $(+8.6 \%)$ and opportunity of employment associated with entrepreneurship $(+6.6 \%)$, as well as a lower entrepreneurial intention $(-0.21 \%)$. There is an increase in entrepreneurship among young people. In both countries, less than $10 \%$ of entrepreneurs are international. Finally, Spain stood out in 2018 for a TEA slightly higher than that of Poland (6.39\% vs. $5.24 \%$, respectively) and a higher perception of entrepreneurship competencies ( $48.46 \%$ vs. $46.60 \%$, respectively) (www.gemconsortium.org). 


\subsection{Data Analysis}

The study was carried out in the months of September 2018 to May of 2019 using a quantitative method that was descriptive and causal. The partial least squares structural equation modeling approach (PLS-SEM) has been used in this study for its advantages in the study of human behavior $[150,151]$, for its optimal predictive and exploratory potential using reflective indicators, because it does not require normal distribution of data and because it allows the use of a wide range of sample sizes [152]. As carried out by other authors, the analysis of the data was done independently for Japan and Spain [153]. It has been used the Partial Least Squares (PLS) model version 3.2.4 [154] to analyze the measurement model, the structural model and to perform the PLS-MGA multigroup analysis. To carry out the multigroup analysis, the measurement invariance was analyzed using MICOM; and a new approach developed for PLS-SEM [51,155-157].

\subsection{Sample and Data Collection}

The population of the study was young people from Poland and Spain. It has been taken into account that university students are a good representation of generation $Y$, as suggested by other authors [32,158]. Therefore, after realizing a cluster study by degrees and courses, the two final samples were made through random sampling of students representatively in Spanish and Poland universities. For a more accurate assessment, the effect size $(0.15)$ and power $(0.90)$ indicator were specified $[159,160]$. First, the characteristics of the population of both universities were identified, in relation to the number of students and gender according to the degrees and courses, as well as the sample sizes of both institutions. As proposed by Ramsey and Hewitt [161], the representativeness of the sample in terms of age, gender and academic profile were achieved by clearly specifying the level of data quality and sampling design. This has allowed consistency, diversity, and transparency. Taking all this into account, the population data distributed by degrees, gender and study programs were requested from the two universities' administration, with the corresponding percentages. These percentages were taken into account in the sampling. Data from both countries concerned the academic year of 2018/2019. In the case of Poland, 1444 students studied at the Faculty of Engineering Management, including 794 women and 650 men. Students attending the following programs were involved in the study: Management, Logistics, Service Management and Engineering, Production Management and Engineering. In Spain, 2279 students studied at the Faculty of Economy, Business and Tourism (957 men and 1322 women). In Poland, the sample was $26 \%$ of the population, in Spain approximately $15 \%$. The days and hours were chosen at random to apply the questionnaire. The process was followed in two rounds at both universities until the samples with the appropriate characteristics and size were completed. Performed the Mann-Whitney test, it was found that only two of the fourteen variables observed had asymptotic bilateral significance greater than 0.05 , which is why it is confirmed that the two samples are independent [162]. Initially, the total sample included 47 more subjects who were eliminated because they responded with the same score to all the items or because they left some item unanswered, which indicates that the answer was $93.48 \%$. The subjects (Table 1 ) were aged between 18 and 24 years old $(97 \%)$. The percentage of men and women in the samples is similar to that in the degrees in each of the two countries. Though in the selected Spanish university the total number of students in 2018 exceeded 20,000, and in the Polish university, more than 13,000. The samples sizes are more than the minimum requirement and in accordance with the minimum of 100 subjects when using structural equations (PLS method) [163]. Although the two samples meet the minimum sample size criteria, they are not the same size. The guideline to consider group sample size differences is when one group is more than $50 \%$ larger than the other [164]. To verify that these are two independent samples, the Mann-Whitney-U test was applied, whose result was 50,000 and a value of $\mathrm{P}$ (asymptotic significance, 2 -sided) less than 0.05 (Pab $<0.05)$ for every twelve variables observed. It can be safely concluded that the size of both samples was adequate for the purposes of this study. 
Table 1. Details of the sample

\begin{tabular}{ccccccc}
\hline \multirow{2}{*}{ Gender } & \multicolumn{9}{c}{ Country } & \multirow{2}{*}{ Total } & \multirow{2}{*}{$\%$} \\
\cline { 2 - 5 } & \multicolumn{2}{c}{ Spain (\%) } & \multicolumn{2}{c}{ Poland (\%) } & & \\
\cline { 2 - 5 } & Number & \% & Number & \% & \\
\hline Male & 144 & $42.48 \%$ & 175 & $45.81 \%$ & 319 & $44.24 \%$ \\
Female & 195 & $57.52 \%$ & 207 & $54.19 \%$ & 402 & $55.76 \%$ \\
Total & 339 & $100.00 \%$ & 382 & $100.00 \%$ & 721 & $100.00 \%$ \\
\hline
\end{tabular}

\subsection{Measurements}

A questionnaire designed ad hoc was used as a tool for collecting data. To carry out the design of the scale, we proceed with the analysis of the variables, the relationships, and the appropriate measures for the proposed model, thus, generating content validity. Authors considered the observation from the recent literature that the variables included in this study were usually measured by means of a small number of items, thus, avoiding the methodological problems and the costs derived from the use of multiple indicators [165]. Next, the Delphi technique was used with two groups of experts to construct, through two rounds, the definitive content of items and relationships. After a pretest, the final questionnaire included 14 items (see Table 2) designed following the principles of brevity and simplicity using a Likert scale with 5 response alternatives (1: No agreement to 5: Total agreement). It also included a control item related to the country to which the subject belonged.

For the design of the two items related to beliefs, previous studies by Fang et al. [166] and Jahanshahi et al. [25] have been consulted. The reagents associated with the social norm have been developed from the contributions of Ajzen and Cote [71] and Gächter and Renner [167]. Ajzen and Fishbein studies have been considered for the design of the items related to the values $[70,113]$. The items associated with the attitude have been elaborated, starting from the indications of Ajzen and Fishbein [70] and Tomczy et al. [113]. In the design of the items linked to motivation, we started with the studies of Fayolle and Liñán [8]. The two items related to self-efficacy are taken into account the contributions of Cho and Lee [120] and Kim and Jang [144]. Finally, the items related to the intention have been elaborated from the work of Liñán and Fayolle [61] and Fuller et al. [23] 
Table 2. Descriptive data (in Spain $\mathrm{N}=339$, in Poland $\mathrm{N}=382$ )

\begin{tabular}{|c|c|c|c|c|c|c|}
\hline \multirow{2}{*}{ Items $^{1}$} & \multicolumn{2}{|c|}{$\%$} & \multicolumn{2}{|c|}{ Median } & \multicolumn{2}{|c|}{ Standard Deviation } \\
\hline & $\mathrm{ES}^{2}$ & $\mathrm{PL}^{3}$ & ES & PL & ES & PL \\
\hline $\begin{array}{l}\text { EB1: Education must } \\
\text { enable students to } \\
\text { become entrepreneurs }\end{array}$ & $84.96 \%$ & $83.87 \%$ & 4.25 & 4.19 & 0.86 & 0.89 \\
\hline $\begin{array}{l}\text { EB2: Entrepreneurship } \\
\text { must be encouraged at } \\
\text { universities }\end{array}$ & $87.43 \%$ & $84.40 \%$ & 4.37 & 4.22 & 0.80 & 0.89 \\
\hline $\begin{array}{l}\text { SN1: Me being an } \\
\text { entrepreneur would be } \\
\text { perceived well by } \\
\text { my friends }\end{array}$ & $85.66 \%$ & $84.08 \%$ & 4.29 & 4.20 & 0.80 & 0.92 \\
\hline $\begin{array}{l}\text { SN2: My family would } \\
\text { accept that I was } \\
\text { an entrepreneur }\end{array}$ & $85.84 \%$ & $87.70 \%$ & 4.29 & 4.38 & 0.83 & 0.83 \\
\hline $\begin{array}{l}\text { VA1: Entrepreneurship } \\
\text { has value because it gives } \\
\text { autonomy and freedom }\end{array}$ & $76.99 \%$ & $78.85 \%$ & 3.85 & 3.94 & 0.97 & 0.89 \\
\hline $\begin{array}{l}\text { VA2: Entrepreneurship } \\
\text { has value because it gives } \\
\text { you work and life } \\
\text { in dignity }\end{array}$ & $76.28 \%$ & $89.37 \%$ & 3.81 & 4.02 & 0.97 & 0.87 \\
\hline $\begin{array}{l}\text { AT1: Entrepreneurship } \\
\text { has more advantages than } \\
\text { disadvantages }\end{array}$ & $74.69 \%$ & $81.62 \%$ & 3.73 & 4.08 & 1.03 & 0.83 \\
\hline $\begin{array}{l}\text { AT2: I am in favor of } \\
\text { entrepreneurship and the } \\
\text { creation of companies }\end{array}$ & $89.91 \%$ & $89.48 \%$ & 4.50 & 4.47 & 0.61 & 0.69 \\
\hline $\begin{array}{l}\text { MO1: I would be } \\
\text { motivated to be an } \\
\text { entrepreneur because I } \\
\text { could achieve more }\end{array}$ & $78.58 \%$ & $86.28 \%$ & 3.93 & 4.31 & 0.96 & 0.82 \\
\hline $\begin{array}{l}\text { MO2: I would be } \\
\text { motivated to be an } \\
\text { entrepreneur because it } \\
\text { would bring me more } \\
\text { resources and benefits }\end{array}$ & $73.63 \%$ & $86.86 \%$ & 3.68 & 4.34 & 1.03 & 0.82 \\
\hline $\begin{array}{l}\text { SE1: I think I would be a } \\
\text { successful entrepreneur if } \\
\text { I created a company }\end{array}$ & $71.15 \%$ & $75.45 \%$ & 3.56 & 3.77 & 0.92 & 0.89 \\
\hline $\begin{array}{l}\text { SE2: I am confident that I } \\
\text { would be able to create } \\
\text { a company }\end{array}$ & $67.96 \%$ & $81.10 \%$ & 3.40 & 4.06 & 1.22 & 0.92 \\
\hline $\begin{array}{l}\text { IE1: I intend to be } \\
\text { an entrepreneur }\end{array}$ & $65.49 \%$ & $71.88 \%$ & 3.27 & 3.59 & 1.21 & 1.03 \\
\hline $\begin{array}{l}\text { IE2: I am thinking of } \\
\text { establishing my own } \\
\text { company in the future }\end{array}$ & $67.61 \%$ & $76.13 \%$ & 3.38 & 3.81 & 1.25 & 1.07 \\
\hline
\end{tabular}




\section{Results}

\subsection{Descriptive Data}

All the items (14) reached an overall score higher than $65 \%$ of the maximum possible value $(100 \%)$ if all the subjects had valued the item with five points (see Table 2). As suggested in the GEM reports, it is confirmed that the Poles declare that they have a greater entrepreneurial intention, are more motivated, attach more importance to values and have a more favorable attitude towards entrepreneurship than Spaniards. However, the results of the discriminant analysis carried out between both samples showed that the only significant differences occurred in the items AT1 and MO2, with the Poles being the ones that tend to score both items higher. The discriminant analysis showed a high significance of the M. de Box test $(\mathrm{P}=0.000)$, reduced levels of the eigenvalue and the canonical correlation ( 0.230 and 0.320 , respectively), as well as a high value of the Wilks Lambda test $(0.851)$.

\subsection{Identification of Latent Variables}

To identify the latent variables or constructs to which the items belong, an exploratory factor analysis with varimax rotation was first conducted for Poland and Spain, using the principal component method, the Kaiser-Meyer-Olkin test (KMO), the Bartlett test of sphericity and the Cronbach alpha reliability statistic. This process is common in studies by other authors [168,169]. After a series of analyses, a structure of seven factors or latent variables was obtained (see Table 3). The inclusion of two items in each factor has been accepted because the variables forming the factors have a high correlation between them (greater than 0.70) and a reduced correlation with other variables [170]. The latent factors or variables of the model are: EB: Education beliefs; SN: Social norm; VA: Values; AT: Attitude; MO: Motivation; SE: Self-efficacy; EI: Entrepreneurship intention.

Table 3. Measurement model: Basic data ${ }^{1}$ (in Spain $\mathrm{N}=339$, in Poland $\mathrm{N}=382$ )

\begin{tabular}{|c|c|c|c|c|c|c|c|}
\hline \multirow{2}{*}{ Construct } & \multirow{2}{*}{ Items } & \multicolumn{2}{|c|}{ Loading $\lambda>0.70$} & \multicolumn{2}{|c|}{$\mathrm{CR}^{2}>0.70$} & \multicolumn{2}{|c|}{$\mathrm{AVE}^{3}>0.50$} \\
\hline & & Spain & Poland & Spain & Poland & Spain & Poland \\
\hline \multirow{2}{*}{$\begin{array}{l}\text { EB: Education } \\
\text { beliefs }\end{array}$} & EB1 & 0.937 & 0.897 & \multirow{2}{*}{0.898} & \multirow{2}{*}{0.857} & \multirow{2}{*}{0.816} & \multirow{2}{*}{0.750} \\
\hline & EB2 & 0.868 & 0.834 & & & & \\
\hline \multirow{2}{*}{ SN: Social norm } & SN1 & 0.894 & 0.909 & \multirow{2}{*}{0.917} & \multirow{2}{*}{0.913} & \multirow{2}{*}{0.847} & \multirow{2}{*}{0.840} \\
\hline & SN2 & 0.947 & 0.923 & & & & \\
\hline \multirow{2}{*}{ VA: Values } & VA1 & 0.834 & 0.826 & \multirow{2}{*}{0.819} & \multirow{2}{*}{0.847} & \multirow{2}{*}{0.693} & \multirow{2}{*}{0.735} \\
\hline & VA2 & 0.831 & 0.888 & & & & \\
\hline \multirow{2}{*}{ AT: Attitude } & AT1 & 0.850 & 0.686 & \multirow{2}{*}{0.789} & \multirow{2}{*}{0.793} & \multirow{2}{*}{0.652} & \multirow{2}{*}{0.661} \\
\hline & AT2 & 0.762 & 0.924 & & & & \\
\hline \multirow{2}{*}{ MO: Motivation } & MO1 & 0.917 & 0.912 & \multirow{2}{*}{0.872} & \multirow{2}{*}{0.888} & \multirow{2}{*}{0.774} & \multirow{2}{*}{0.798} \\
\hline & $\mathrm{MO} 2$ & 0.841 & 0.875 & & & & \\
\hline \multirow{2}{*}{ SE: Self-efficacy } & SE1 & 0.895 & 0.875 & \multirow{2}{*}{0.910} & \multirow{2}{*}{0.883} & \multirow{2}{*}{0.834} & \multirow{2}{*}{0.790} \\
\hline & SE2 & 0.931 & 0.903 & & & & \\
\hline \multirow{2}{*}{$\begin{array}{l}\text { EI: Entrepreneur. } \\
\text { Intention }\end{array}$} & EI1 & 0.965 & 0.919 & \multirow{2}{*}{0.962} & 0.914 & 0.926 & 0.842 \\
\hline & EI2 & 0.960 & 0.916 & & & & \\
\hline
\end{tabular}

${ }^{1}$ EB: Education beliefs, SN: Social norm, VA: Values, AT: Attitude, MO: Motivation, SE: Self-efficacy, EI: Entrepreneurship intention. ${ }^{2}$ CR: Composite reliability. ${ }^{3}$ AVE: average variance extracted.

\subsection{Analysis of the Model in the PLS Context of Structural Equations}

First, and to test the six hypotheses of the proposed causal model, the measurement model was evaluated for Spain and Poland, which relates the observable variables to their latent variable [170]. 
The analysis of the measurement model involves studying the reliability (individual and composite) and the validity (convergent and discriminant) of the relationships between the observed variables (items) and the latent variables with which they are associated. The study of individual reliability showed that the observed variables reached the minimum level required $(\lambda \geq 0.70)$, in the case of Spain, as well as Poland (Table 3). Therefore, it was accepted that the indicators were part of their corresponding constructs [171]. The study of composite reliability (CR), an indicator similar to Cronbach's alpha though more appropriate than Cronbach's in the framework of structural equations, showed all values were above 0.70, in the case of Poland, as well as Spain (Table 3). This shows that the measurement model was internally consistent and that all the indicators or variables observed were measuring their corresponding latent variable [157].

To evaluate the convergent validity of the model, the average variance extracted (AVE) was calculated, which provides information on the amount of variance that a construct obtains from its indicators in relation to the amount of variance, due to measurement error. In all cases, the result was greater than 0.50 , so it was found that more than $50 \%$ of the variance of the construct was due to its indicators [171] (Table 3).

Regarding the discriminant validity, this implies that each construct is significantly different from the rest of constructs with which it is not related according to the theory. To calculate the discriminant validity and following Fornell and Larcker [172], it was first verified that the square root of average variance extracted (AVE) (on the diagonal of Table 4) was greater than the variance shared between the construct and the other constructs of the model (data that are not found in the diagonal of Table 4) [173].

Table 4. Discriminant validity: Criteria of Fornell Larcker (in Spain $\mathrm{N}=339$, in Poland $\mathrm{N}=382$ )

\begin{tabular}{ccccccccccccccc}
\hline \multicolumn{1}{c}{ Spain } & \multicolumn{1}{c}{ Poland } \\
\hline & EB & SN & VA & AT & MO & SE & EI & EB & SN & VA & AT & MO & SE & EI \\
\hline EB & 0.903 & & & & & & & 0.866 & & & & & & \\
SN & 0.055 & 0.920 & & & & & & 0.319 & 0.916 & & & & \\
VA & 0.051 & 0.262 & 0.833 & & & & & 0.344 & 0.298 & 0.857 & & & \\
AT & 0.140 & 0.273 & 0.488 & 0.807 & & & & 0.315 & 0.348 & 0.403 & 0.813 & & \\
MO & 0.150 & 0.504 & 0.397 & 0.474 & 0.880 & & & 0.445 & 0.455 & 0.464 & 0.426 & 0.894 & \\
SE & 0.076 & 0.459 & 0.330 & 0.445 & 0.495 & 0.913 & & 0.231 & 0.372 & 0.275 & 0.311 & 0.457 & 0.889 & \\
EI & 0.158 & 0.378 & 0.277 & 0.416 & 0.553 & 0.703 & 0.962 & 0.245 & 0.240 & 0.270 & 0.238 & 0.479 & 0.641 & 0.917 \\
\hline EB: Education beliefs, SN: Social & norm, VA: Values, AT: Attitude, MO: Motivation, SE: Self-efficacy, \\
EI: Entrepren. intention. & & & & &
\end{tabular}

Secondly, it was used the heterotrait-monotrait (HTMT) ratio, which has been established as a superior criterion [51]. The present study uses the more conservative level of 0.85 to assess discriminant validity in all cases (Spain and Poland). Finally, the matrix of cross-factor loadings was also obtained [174]. The factor loadings, or Pearson correlations of the indicators with their own construct, should be greater than those maintained with the rest of the constructs, as was found. Therefore, the indicators were more correlated with their own construct than with others. Therefore, it can be said that the measurement model is valid and reliable.

Regarding the evaluation of the structural model, which relates some constructs with others [170], the collinearity was analyzed, both for Spain and Poland; the algebraic sign, magnitude and statistical significance of the structural path coefficients; the R2 values (variance explained); the f2 effect size; The Q2 indicator, the GoF test (Goodness-of-Fit) (predictive relevance) and the SRMR indicator of global adjustment of the model [175]. In the first place, it was verified that there was no multicollinearity between the constructs, since the variance inflation index (IVF) was, in any case, lower than 3.3 [156]. Secondly, it was verified the sign of the causal relationships between the constructs and the weight of these relations, both in the case of Poland and Spain (Table 5). Regarding the sign of the causal relationships, it was found that all had the same positive sign as their corresponding hypothesis, which is why no hypothesis had to be rejected. Regarding the weight of the causal relationships, 
it was found that in Spain, except in the case of the relationship between beliefs (EB) and social norm $(\mathrm{SN})$, the coefficient paths $(\beta)$ (standardized regression weights) reached levels above the minimum acceptable level $(\beta \geq 0.2)$ [173], or even at the optimal level $(\beta \geq 0.3)$ [176]. The causal relationships with greater weight in the case of Spain were those that linked self-efficacy (SE) with the entrepreneurial intention (EI) $(\mathrm{H} 6: \beta=0.703)$ and the relationship between motivation $(\mathrm{MO})$ and self-efficacy $(\mathrm{SE})$ (H5: $\beta=0.495)$ (Table 5). In the case of Poland, the relationships with greater weight were also those corresponding to the relationship between self-efficacy (SE) and entrepreneurial intention (EI) (H6: $\beta=0.641$ ) and the relationship between motivation (MO) and self-efficacy (SE) (H5: $\beta=0.457$ ) (Table 5). It is worth highlighting the greater weight of the first two relations (H1 and H2) in the case of Poland, and the greater weight in the rest of the relations (H3 to H6) in the case of Spain. The analysis of the significance of the relationships was carried out by bootstrap with 5000 resamples and 5000 permutations [153]. All the relationships were significant except for the one corresponding to the first hypothesis (H1) in the case of Spain. Therefore, all hypotheses of the proposed model are accepted except $\mathrm{H} 1$ in the case of Spain.

Table 5. Relations data (in Spain $\mathrm{N}=339$, in Poland $\mathrm{N}=382$ )

\begin{tabular}{cccccccccccc}
\hline \multirow{2}{*}{ Hypo-Thesis } & \multirow{2}{*}{ Relations } & \multicolumn{4}{c}{ Spain } & \multicolumn{5}{c}{ Poland } \\
\cline { 3 - 11 } & & Paths $(\boldsymbol{\beta})$ & $\mathbf{t}$ & $\mathbf{P}$ Val. & $\mathbf{f 2}$ & Conf. & Paths $(\boldsymbol{\beta})$ & $\mathbf{t}$ & P Val. & f2 & Conf. \\
\hline $\mathrm{H} 1$ & $\mathrm{~EB} \rightarrow \mathrm{SN}$ & 0.055 & 0.879 & 0.380 & 0.003 & No & 0.319 & 5.809 & 0.000 & 0.113 & Yes \\
$\mathrm{H} 2$ & $\mathrm{SN} \rightarrow \mathrm{VA}$ & 0.262 & 4.266 & 0.000 & 0.073 & Yes & 0.298 & 5.621 & 0.000 & 0.097 & Yes \\
$\mathrm{H} 3$ & $\mathrm{VA} \rightarrow \mathrm{AT}$ & 0.488 & 12.109 & 0.000 & 0.313 & Yes & 0.403 & 7.911 & 0.000 & 0.194 & Yes \\
$\mathrm{H} 4$ & $\mathrm{AT} \rightarrow \mathrm{M} \mathrm{O}$ & 0.474 & 11.664 & 0.000 & 0.290 & Yes & 0.426 & 7.199 & 0.000 & 0.221 & Yes \\
$\mathrm{H} 5$ & $\mathrm{MO} \rightarrow \mathrm{SE}$ & 0.495 & 12.524 & 0.000 & 0.324 & Yes & 0.457 & 8.548 & 0.000 & 0.263 & Yes \\
$\mathrm{H} 6$ & $\mathrm{SE} \rightarrow \mathrm{EI}$ & 0.703 & 30.724 & 0.000 & 0.975 & Yes & 0.641 & 19.041 & 0.000 & 0.696 & Yes \\
\hline
\end{tabular}

EB: Education beliefs, SN: Social norm, VA: Values, AT: Attitude, MO: Motivation, SE: Self-efficacy, EI: Entrepreneurship intention.

In Figures 2 and 3 models of the relations between personal factors and entrepreneurial intention, separately for Poland and Spain (in Spain N = 339, in Poland N = 382).

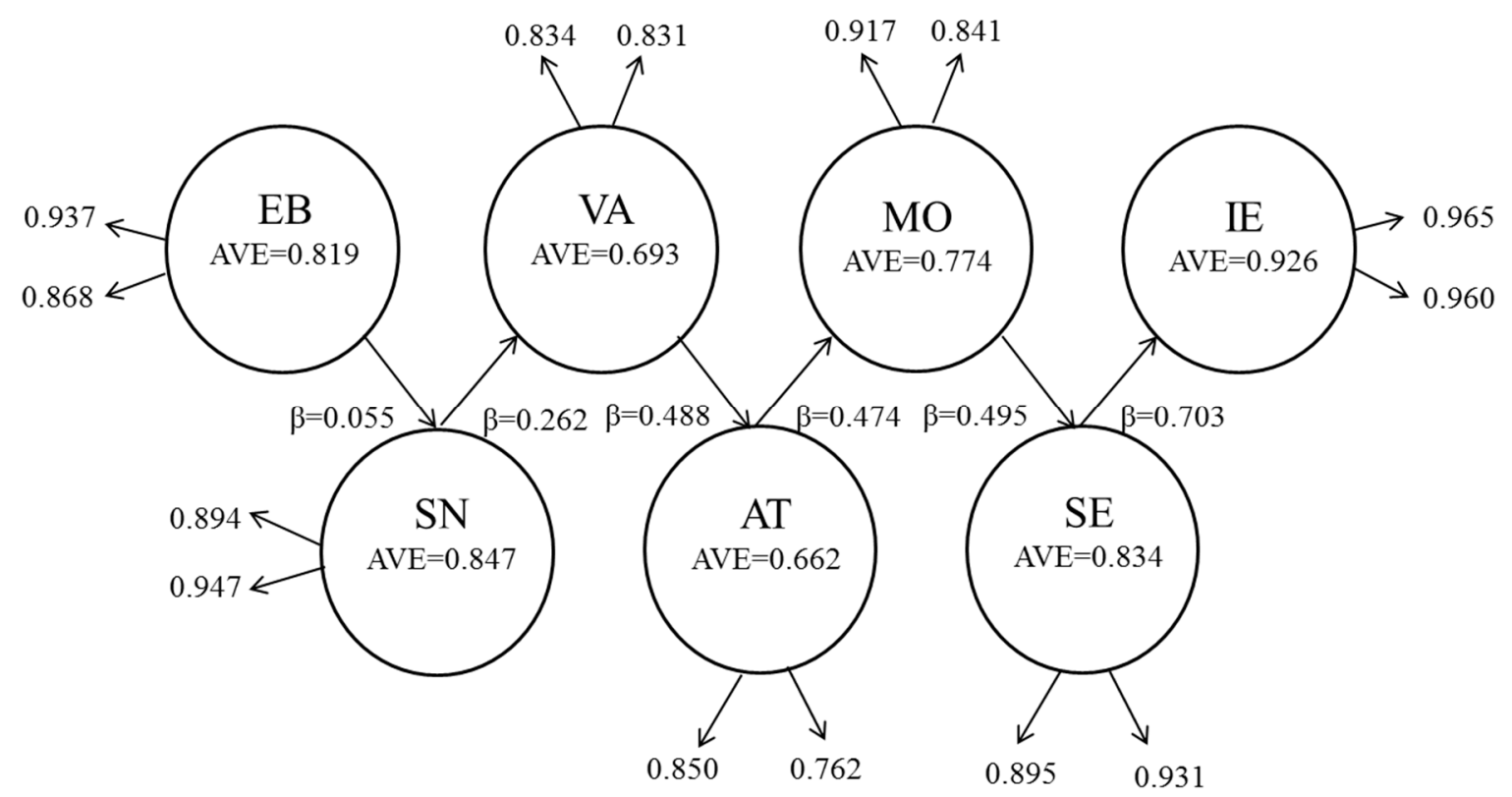

Figure 2. Spanish model of the relations between personal factors and entrepreneurial intention. EB: Education beliefs, SN: Social norm, VA: Values, AT: Attitude, MO: Motivation, SE: Self-efficacy, EI: Entrepreneurship intention. 


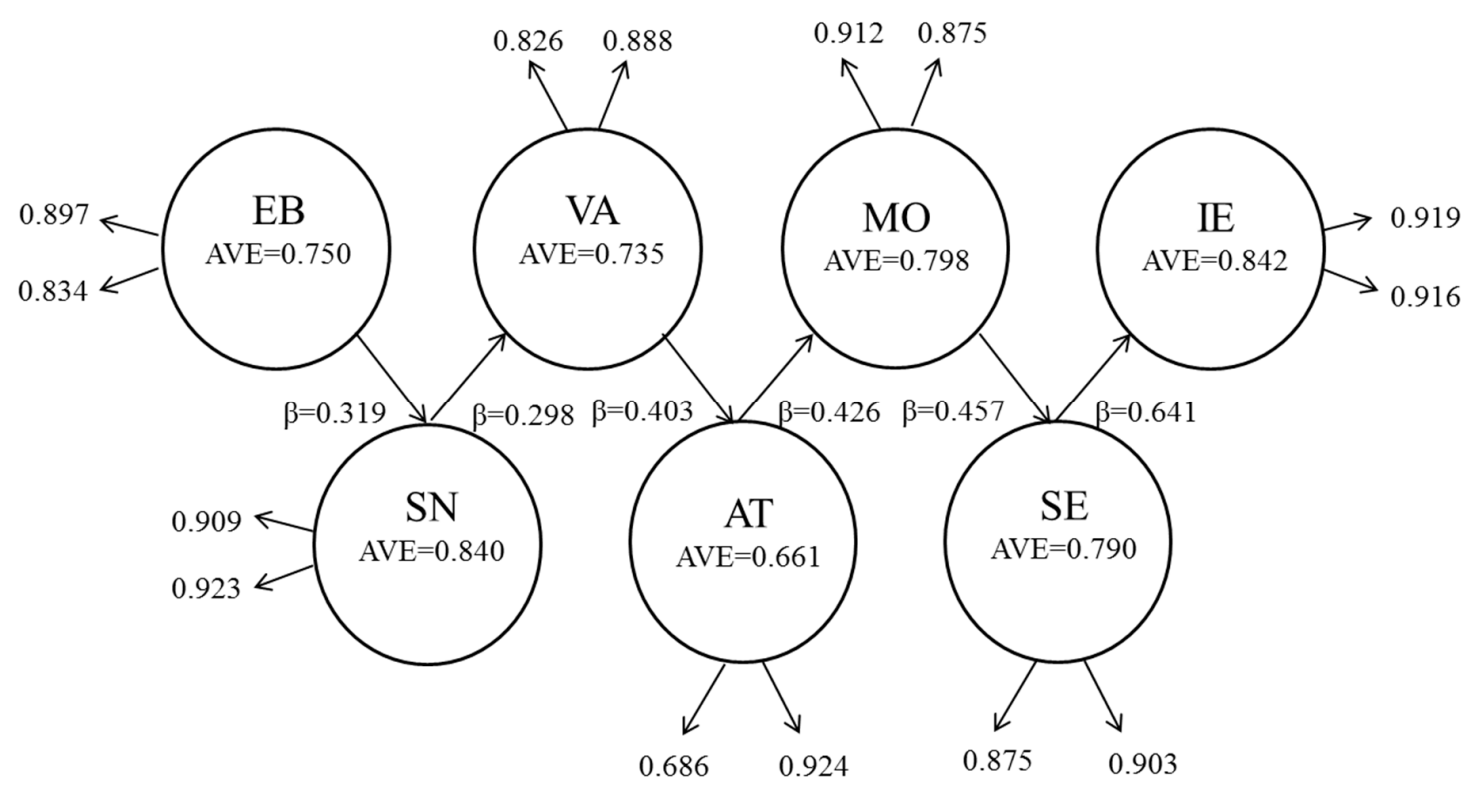

Figure 3. Polish model of the relations between personal factors and entrepreneurial intention. EB: Education beliefs, SN: Social norm, VA: Values, AT: Attitude, MO: Motivation, SE: Self-efficacy, EI: Entrepreneurship intention.

In relation to indicator R2 (coefficient of determination) (Table 6), which reports on the amount of variance explained by the model in each dependent latent variable, $R 2$ values above 0.2 are relatively high and acceptable by behavioral research standards $[153,157]$ In the case of Spain, the variance of the dependent variable $(E I)$ is better explained $(R 2=0.494)$ than in the case of Poland $(R 2=0.436)$.

Table 6. R2, Q2 and GoF indicators (in Spain $\mathrm{N}=339$, in Poland $\mathrm{N}=382$ )

\begin{tabular}{cccccc}
\hline \multirow{2}{*}{ Key } & \multirow{2}{*}{ Construct } & \multicolumn{2}{c}{ Spain } & \multicolumn{2}{c}{ Poland } \\
\cline { 3 - 6 } & & $\mathbf{R}^{\mathbf{2}}>\mathbf{0 . 2 0}$ & $\mathbf{Q}^{\mathbf{2}}>\mathbf{0}$ & $\mathbf{R}^{\mathbf{2}}>\mathbf{0 . 2 0}$ & $\mathbf{Q}^{\mathbf{2}}>\mathbf{0}$ \\
\hline SN & Social norm & 0.003 & 0.002 & 0.102 & 0.077 \\
VA & Values & 0.068 & 0.044 & 0.089 & 0.057 \\
AT & Attitude & 0.238 & 0.147 & 0.163 & 0.100 \\
MO & Motivation & 0.225 & 0.166 & 0.181 & 0.131 \\
SE & Self-efficacy & 0.245 & 0.195 & 0.208 & 0.155 \\
EI & Entrepreneurship & 0.494 & 0.436 & 0.410 & 0.329 \\
& intention & & & & 0.386 \\
\end{tabular}

EB: Education beliefs, SN: Social norm, VA: Values, AT: Attitude, MO: Motivation, SE: Self-efficacy, EI: Entrepreneurship intention.

On the other hand, the $\mathrm{f} 2$ indicator assesses the degree to which an exogenous construct contributes to explain a specific endogenous construct in terms of $\mathrm{R} 2$ [159]. The values were adequate and above the minimum accepted level (0.15), except in the case of the first two hypotheses (H1 and H2), both in the case of Spain and Poland (Table 6).

Regarding the indicator Q2 (predictive relevance of the dependent constructs), it reached the values above zero in all cases (Q2 $\geq 0)$ [177] (Table 6).

Additionally, the GoF test, which represents the geometric mean between the average of the AVE indicator and the average of R2 in relation to the endogenous constructs [178], was calculated. The result was higher than the minimum acceptable value ( $\mathrm{GoF} \geq 0.360)$ (Table 6), considering the most unfavorable situation for this test, which is that of samples with high effects [178]. 
Finally, the SRMR composite factor model was applied to determine the extent to which the model fitted the data. In all cases, this indicator was below 0.08, thus, confirming the good of the models $($ SRMR Spain $=0.069$, SRMR Poland $=0.071)$ [179]. Therefore, the predictive power of the model is accepted in the case of both countries.

The results show that the structural model is significant.

\subsection{Multigroup Analysis}

To test hypothesis 7 (H7), regarding the existence of significant causal differences between the Spanish and Polish models, a multigroup analysis was carried out. The MGA multigroup analysis is particularly useful for research in a global context of a comparison between countries or cultures, as well as in the analysis of segment differences carried out by age or gender [179]. This analysis was carried out using two nonparametric tests: The MGA test [49], and the permutation test [50]. These two tests are considered as the most conservative PLS-SEM techniques in the context of the structural equation model PLS-SEM [152].

Before performing the multigroup analysis, the measurement invariance was first checked in the context of PLS-SEM. The procedure called MICOM [51] (Table 7) is one of the most appropriate and is carried out in three steps. The first step is to examine the configuration invariance, which implies checking that identical indicators have been used in both groups, as well as an identical data treatment and identical configuration of the algorithm [51]. The second step is to check the invariance of the composition, which occurs when composite scores are created equally across groups [180]. Finally, the third step is to check the invariance of means and variances. When the invariance is confirmed in this third step for the case of means or in the case of variances, but not in both cases, it is concluded that partial invariance exists. It is when the partial invariance of the measurement for both groups is achieved for all the constructs of the model when the multigroup comparison can be carried out. In this study, the stability of the invariance in the first two steps has been confirmed. However, total invariance has not been achieved, according to the results of step 3 (I and II), which is why it is stated that there is partial verification of invariance, and therefore, both groups can be compared.

Table 8 shows the path differences obtained in the Spanish and Polish models, as well as the significance of said differences, both in the MGA analysis and in the permutation test. In the case of the MGA analysis, a p-value lower than 0.05 or higher than 0.95 indicates a level of significance to be taken into account between path coefficients associated with a specific hypothesis, which means that this causal relationship is significantly different between the two countries $[49,155]$. In the case of the permutation test, the differences are significant only when the value of $\mathrm{p}$ is less than 0.05 . According to both criteria, the only causal relationship that is significantly different between the two countries is that which refers to the first hypothesis (H1), which has the greatest weight in the case of Poland. There are no significant differences between Spain and Poland in the case of the causal relationships associated with the other five hypotheses of the model. Therefore, it can be affirmed that there are no significant differences between the causal models of both countries, thus, confirming the seventh hypothesis (H7). However, the weight of the relations between the first two hypotheses is greater in the case of Poland, in the rest of the hypotheses the weight of the relations is greater in the case of Spain. 
Table 7. Results of invariance measurement testing using permutation (in Spain $\mathrm{N}=339$, in Poland $\mathrm{N}=382$ ).

\begin{tabular}{|c|c|c|c|c|c|c|c|c|c|c|c|}
\hline \multirow{3}{*}{ Dim } & \multirow{3}{*}{$\begin{array}{c}\text { Step 1 } \\
\begin{array}{c}\text { Configural } \\
\text { Invariance }\end{array}\end{array}$} & \multicolumn{3}{|c|}{ Step 2} & \multirow{2}{*}{\multicolumn{3}{|c|}{$\begin{array}{c}\text { Step } 3 \text { (I) } \\
\text { Equal Mean Assessment }\end{array}$}} & \multirow{2}{*}{\multicolumn{3}{|c|}{$\begin{array}{c}\text { Step 3(II) } \\
\text { Equal Variance Assessment }\end{array}$}} & \multirow{3}{*}{$\begin{array}{c}\text { Full Measuremen } \\
\text { Invariance } \\
\text { Established }\end{array}$} \\
\hline & & \multicolumn{2}{|c|}{$\begin{array}{c}\text { Compositional } \\
\text { Invariance }\end{array}$} & \multirow{2}{*}{$\begin{array}{c}\text { Partial } \\
\text { Measurement } \\
\text { Invariance } \\
\text { Established }\end{array}$} & & & & & & & \\
\hline & & $C=1$ & $\begin{array}{l}\text { Confid. } \\
\text { Interval }\end{array}$ & & Dif & $\begin{array}{l}\text { Confid. } \\
\text { Interval }\end{array}$ & Equal & Dif & $\begin{array}{c}\text { Confid. } \\
\text { Interval }\end{array}$ & Equal & \\
\hline EB & Yes & 0.999 & $\begin{array}{l}(0.956, \\
0.999)\end{array}$ & Yes & 0.148 & $\begin{array}{c}(-0.139 \\
0.144)\end{array}$ & No & -0.046 & $\begin{array}{c}(-0.255, \\
0.245)\end{array}$ & Yes & No \\
\hline $\mathrm{SN}$ & Yes & 0.999 & $\begin{array}{l}(0.996 \\
0.999)\end{array}$ & Yes & 0.000 & $\begin{array}{c}(-0.143 \\
0.149)\end{array}$ & Yes & -0.249 & $\begin{array}{c}(-0.238 \\
0.236)\end{array}$ & No & No \\
\hline VA & Yes & 0.998 & $\begin{array}{l}0.992, \\
0.998) \\
\end{array}$ & Yes & -0.193 & $\begin{array}{c}(-0.146 \\
0.145) \\
\end{array}$ & No & 0.127 & $\begin{array}{c}(-0.218, \\
0.221)\end{array}$ & Yes & No \\
\hline AT & Yes & 0.997 & $\begin{array}{l}0.990 \\
0.997)\end{array}$ & Yes & -0.203 & $\begin{array}{c}(-0.152 \\
0.148)\end{array}$ & No & 0.051 & $\begin{array}{c}(-0.231, \\
0.232)\end{array}$ & Yes & No \\
\hline $\mathrm{MO}$ & Yes & 0.999 & $\begin{array}{l}(0.999 \\
0.999)\end{array}$ & Yes & -0.600 & $\begin{array}{c}(-0.151 \\
0.148)\end{array}$ & No & 0.346 & $\begin{array}{c}(-0.231 \\
0.228)\end{array}$ & No & No \\
\hline SE & Yes & 1.000 & $\begin{array}{l}(0.998 \\
1.000)\end{array}$ & Yes & -0.475 & $\begin{array}{c}(-0.144 \\
0.144)\end{array}$ & No & 0.391 & $\begin{array}{c}(-0.199 \\
0.197)\end{array}$ & No & No \\
\hline EI & Yes & 1.000 & $\begin{array}{l}(1.000 \\
1.000)\end{array}$ & Yes & -0.341 & $\begin{array}{c}(-0.146 \\
0.151)\end{array}$ & No & 0.408 & $\begin{array}{c}(-0.186 \\
0.187)\end{array}$ & No & No \\
\hline
\end{tabular}

EB: Education beliefs, SN: Social norm, VA: Values, AT: Attitude, MO: Motivation, SE: Self-efficacy, EI: Entrepreneurship intention.

Table 8. Multigroup analysis (in Spain $\mathrm{N}=339$, in Poland $\mathrm{N}=382$ )

\begin{tabular}{cccccc}
\hline \multirow{2}{*}{ Hypothesis } & \multirow{2}{*}{ Relationship } & \multirow{2}{*}{ Path Coefficient Difference } & \multicolumn{2}{c}{ P-Value Difference } & \multirow{2}{*}{ Supported } \\
\cline { 3 - 4 } & & & Henseler's MGA & Permutation Test & \\
\hline $\mathrm{H} 1$ & $\mathrm{~EB} \rightarrow \mathrm{SN}$ & 0.264 & 1.000 & 0.001 & Yes/Yes \\
$\mathrm{H} 2$ & $\mathrm{SN} \rightarrow \mathrm{VA}$ & 0.036 & 0.679 & 0.650 & No/No \\
$\mathrm{H} 3$ & $\mathrm{VA} \rightarrow \mathrm{AT}$ & 0.085 & 0.101 & 0.187 & No/No \\
$\mathrm{H} 4$ & $\mathrm{AT} \rightarrow \mathrm{MO}$ & 0.048 & 0.250 & 0.495 & No/No \\
$\mathrm{H} 5$ & $\mathrm{MO} \rightarrow \mathrm{SE}$ & 0.038 & 0.274 & 0.528 & No/No \\
$\mathrm{H} 6$ & $\mathrm{SE} \rightarrow \mathrm{EI}$ & 0.062 & 0.089 & 0.102 & No/No \\
\hline
\end{tabular}

EB: Education beliefs, SN: Social norm, VA: Values, AT: Attitude, MO: Motivation, SE: Self-efficacy, EI: Entrepreneurship intention. 


\section{Discussion and Theoretical Implications}

Taking into account the scores of the items, it can be affirmed that the results of the descriptive analysis confirm the GEM reports and the affirmations of numerous authors about the importance that entrepreneurship has for young people, as well as the relevance that university students give to the creation of a company as a work alternative [37]. Likewise, the data from the GEM reports on the differences between Poland and Spain regarding entrepreneurship are also confirmed: Young people in Poland declare that they have a greater entrepreneurial intention, are more motivated, attach more importance to values and have a more favorable to entrepreneurship than young Spaniards. However, these differences are not very significant. Additionally, although the items related to the intention have obtained a high score, they are the variables that have been least valued by the young people of both countries. This may be due to the combined effect of several factors: Young people are still immersed in their educational process; the sample included students of the first courses who generally have a less entrepreneurial intention; and the sample included a representative percentage of women who display relatively less entrepreneurial intention too.

Following authors earlier research [181], and the suggestions of other authors, which have been included in the theoretical framework of this study, a new explanatory causal model has been generated of the entrepreneurial intention of the young people that are complete in relation to the number of variables that it incorporates. The proposed model complements previous reference models and includes other variables and different relationships, such as beliefs or motivation. By including the beliefs in the model, as a variable that initiates the chain of effects that culminate in the entrepreneurial intention, responds to the predominant thinking in this field. This current demands inclusion in the models of certain previous sociocultural precursors [111,112,165].

On the other hand, the presented model demonstrates the existence of a series of subjective variables (beliefs, social norms, values) that are found at the beginning of the model and influence other variables that are more related to the action and behavior of undertaking (motivation, self-efficacy, intention). It is noteworthy that not all variables are in the same plane of consciousness by the subject or are equally manageable by agents and institutions. Subjective variables, such as beliefs, values or the social norm, are formed to a large extent by processes associated with conditioning and modeling, and the other variables depend on them. These results lead to the question of the extent to which entrepreneurship is truly voluntary, intentional and conscious.

In relation to the hypotheses of the proposed model, it should first be noted that the confirmed influence of beliefs on the social norm (H1) gathered in previous studies [165] has been confirmed in this study for the case of Poland, but not in the case of Spain. Therefore, in the case of Spain, the subject's beliefs about the role of education in entrepreneurship have little influence on the expectations and preferences perceived by his relatives about his role as an entrepreneur. This unequal result may be related, in the case of the segment studied and particularly in Spain, with a lower perceived connection on the part of the subject and/or his close associates between the university academic world and entrepreneurship.

Secondly, the influence of the social norm on the values associated with entrepreneurship (H2) has also been confirmed, both in the case of Spain and in Poland, as suggested by other authors in this and other fields $[118,120]$. However, this influence is not very high, and is somewhat higher in the case of Poland. Consequently, the empirically verified compliance principle, by which people tend to adjust to what others expect of them, is somewhat greater in Poland [127]. The weight of this relationship suggests that, in addition to the social norm, there are other factors that influence the values [69].

Third, according to the results of this study, the values about entrepreneurship explain to a large extent the attitudes of young people towards the process of creating new companies (H3) [99,100], to a greater extent in the case of Spain. This result confirms the proposals and findings of other authors in other fields in which the positions of people in favor of an object or behavior are closely related to the assessment made of them [128,129]. On the other hand, once motivation has been included as an intermediate variable between attitude and entrepreneurial intention, as some authors have 
suggested [101,116], the influence of attitude on motivation is confirmed (H4) [131], particularly in the case of Spain. It can be affirmed, therefore, that the favorable attitude toward entrepreneurship exerts a motivational effect in the case of young people [133,134]. This fact is particularly relevant given the high influence that motivation exerts on entrepreneurship $[30,131]$. Additionally, the results show that attitude is a variable that serves as a link between the values, which depend on the social norm and other subjective variables, and certain variables related to the action, such as motivation and intention. [126].

Additionally, the results also show a high causal influence between motivation and self-efficacy to undertake in the case of young people (H5), as has been observed in the literature $[46,141]$. This influence is also greater in the case of Spain. Therefore, it can be affirmed that the motivated young person feels self-sufficient to undertake; that is, he feels more confident and perceives that he will succeed in the creation of the company [141]. This, in turn, increases their alertness to new opportunities, activates their creative problem solving, improves their cognitive flexibility and favors the realization of the effort involved in entrepreneurship [130,131].

The high influence of self-efficacy on the entrepreneurial intention (H6) in the case of young people has been confirmed in this work, also somewhat more in the case of Spain than in Poland [61]. This difference may suggest the greater relative weight of other variables not included in the model on the entrepreneurial intention of the young Poles. However, this result must be contrasted with the data of the GEM, according to which the entrepreneurial intention declared by the Poles is greater than that of the Spanish. The causal relationship between self-efficacy and the entrepreneurial intention is very important if one takes into account that the intention is the variable that best predicts the entrepreneurial behavior and influences the establishment of goals and the effort to be made to create the company by of entrepreneur $[143,144]$.

Finally, the results of the discriminant analysis and the multigroup analysis indicate that the differences in the responses to the items and in the causal relationships of the Polish and Spanish models are not very significant. This may be due to the homogenizing weight inherent in a generational approach according to which young people of Generation $Y$ share global similar perceptions, attitudes and values $[30,147]$. This is important because there is a certain divergence in the literature on the question of the full homogeneity of Generation $\mathrm{Y}$ in all contexts and with respect to all variables $[88,89]$.

\section{Conclusions, Implications and Limitations}

This study has sought to respond to the concerns and suggestions found in the literature regarding the need to carry out studies in greater depth and in a comparative generational and regional context of factors that influence the entrepreneurial intention of young people. This has sought to enrich theoretical and practical knowledge in this field, particularly in the case of the Generation Y of Spain and Poland.

Taking into account that the young people of Spain and Poland value very positively all the observed variables presented, given the high scores of the items, it is concluded that this segment of the population has a favorable predisposition to entrepreneurship in both countries. This predisposition favors action in the educational context and through other institutions to promote entrepreneurship, and thus, contribute to the sustainable development of regions [182-185]. As such, policymakers can use the findings of this research to establish policies to improve the conditions in the ecosystems for sustainable entrepreneurship in their regions. Findings can help them achieve their goal of transitioning to a more sustainable local economy. Specifically, the responses show that there is a potential for action in this field to improve the influence on the entrepreneurial intention in the teaching and learning process [186,187].

A new, significant and complete causal model of intention formation has been proposed that is valid for Spain and Poland, and that has taken as reference the previously existing models, including other variables and relationships proposed by other authors. The model includes exclusively personal variables, given the relevance of said variables in the enterprise. The variables of the model can be 
divided into two groups, subjective variables (e.g., beliefs, social norm) and personal action variables (e.g., motivation, self-efficacy). In the model, the chain of direct and indirect effects that culminates with the entrepreneurial intention begins with the subjective variables which influence action variables.

The importance of the subjective variables, which derives from the scores obtained by the items and by initiating the chain of relationships in the proposed model, suggests that the promotion of entrepreneurship must address social and cultural aspects, in which education plays an important role (in addition to other agents and institutions). On the other hand, the role of subjective variables allows us to conclude that entrepreneurship is a less voluntary process and hints at what could be assumed at first. That is, there is an unconscious and socially determined content in the process of creating a company. Therefore, a challenge is to bring to light the aspects that empower and stop the venture, to manage them.

Despite the relevance of subjective variables, it is a practical and useful model to predict the entrepreneurial intention and influence the entrepreneurship carried out by young people. Therefore, the proposed model, through the variables and the relationships it includes, suggests the aspects on which to influence, taking into account that subjective variables are more difficult to manage. Attitude is a key variable in the model that serves as a link between the subjective variables and the variables related to the action.

The high similarity of the descriptive and causal results allows us to conclude that young people from Spain and Poland share, to a large extent, perceptions about entrepreneurship, from which behaviors will be derived. This indicates the high homogenizing weight of a generational approach, which may lead to the possibility of carrying out homogeneous measures to promote entrepreneurship for the entire segment in an educational context and in different regions. Even so, there are also some differences between both countries that could lead to different measures for both segments.

One of the limitations of this study refers to the selection of the variables under study. There are so many personal factors on which entrepreneurship depends, in addition to contextual factors, that it is very difficult to select with certainty the variables to be included in the model. However, this limitation has been addressed through the inclusion in the proposed model of the personal variables considered most important in the literature, in addition to incorporating others that have been proposed as a novel by various authors. The human capital approach predominates in the literature, according to which the personal variables, which are the object of study, directly influence the intention to undertake, while the contextual variables influence indirectly through personal variables. Subsequent studies could analyze the direct effect of contextual variables on personal variables and the indirect effect on the intention in the youth segment. A second limitation is related to the population to be studied and the selection of the samples, taking into account that a comparison has been carried out at a regional level and that differences may exist within each country. This limitation has been addressed, taking into account the homogenizing effect of generations and the representativeness in this field of university students. However, students may not turn this intention into actual behavior. Students that have shown high intention to adopt an entrepreneurial career path may choose to go in another direction. A further study could be carried out on these students to see if they have turned these intentions into behavior after graduation.

Another limitation of the research may be insufficient signalization of the relationship between entrepreneurial intentions and sustainable development. Literature has just begun researching sustainable entrepreneurship and the complicated interaction between sustainable development and innovative entrepreneurial activity [188]. To understand sustainable entrepreneurship, researchers must explore the pursuit of sustainable development opportunities embedded in ecosystems of entrepreneurship, its interaction with various entities, and its manifestations at the micro, macro and geographical levels [189-196]. New avenues of scientific reflection on sustainable entrepreneurship are revealed with the emergence of concepts, such as sustainable innovation [197] or responsible innovation [198]. 
The mentioned limitations and the results of the study can give an idea of what could be some of the future lines of investigation. Among them, we can highlight the incorporation of other variables and relationships in the models, including the contextual variables, as well as the realization of longitudinal studies, the analysis of other population segments, the intergenerational comparison and the study in other geographical contexts. It could also be interesting to analyze the less conscious nature of the enterprise and the ways of managing it.

Author Contributions: Conceptualization, J.A.M.-G. and U.K.; methodology, J.A.M.-G. and U.K.; software, J.A.M.-G. and F.J.G.-R.; validation, F.J.G.-R. and L.N.; formal analysis, J.A.M.-G. and F.J.G.-R.; investigation, J.A.M.-G. and U.K.; writing—original draft preparation, J.A.M.-G., F.J.G.-R., U.K. and L.N.; writing-review and editing, L.N.; visualization, J.A.M.-G. and F.J.G.-R.

Funding: The research was conducted with the support of the Department of Dirección de Empresas e Historia Económica de la Universidad de La Laguna, Spain and by the Ministry of Science and Higher Education of the Polish Republic (research project number S/WZ/1/2018).

Conflicts of Interest: The authors declare no conflict of interest.

\section{References}

1. Belz, F.M.; Binder, J.K. Sustainable entrepreneurship: A convergent process model. Bus. Strateg. Environ. 2017, 26, 1-17. [CrossRef]

2. Kiselitsa, E.P.; Shilova, N.N.; Liman, I.A.; Naumenko, E.E. Impact of spatial development on sustainable entrepreneurship. Entrep. Sustain. Issues 2018, 6, 890-911. [CrossRef]

3. Filser, M.; Kraus, S.; Roig-Tierno, N.; Kailer, N.; Fischer, U. Etrepreneurship as catalyst for sustainable development: Opening the black box. Sustainability 2019, 11, 4503. [CrossRef]

4. Urbano, D.; Aparicio, S.; Audretsch, D. Twenty-five years of research on institutions, entrepreneurship, and economic growth: What has been learned? Small Bus. Econ. 2018, 53, 21-49. [CrossRef]

5. Liñán, F.; Fernández, J.; Romero, I. Necessity and opportunity entrepreneurship: The mediating effect of culture. Rev. Econ. Mund. 2013, 33, 21-47.

6. Yan, X.; Gu, D.; Liang, C.; Zhao, S.; Lu, W. Fostering sustainable entrepreneurs: Evidence from China college students "Internet Plus"innovation and entrepreneurship competition (CSIPC). Sustainability 2018, 10, 3335. [CrossRef]

7. Badri, R.; Hachicha, N. Entrepreneurship education and its impact on students' intention to start up: A sample case study of students from two Tunisian universities. Int. J. Manag. Educ. 2019, 17, 182-190. [CrossRef]

8. Fayolle, A.; Liñán, F. The future of research on entrepreneurial intentions. J. Bus. Res. 2014, 67, 663-666. [CrossRef]

9. Ahsan, M.; Fernhaber, S.A. Multinational enterprises: Leveraging a corporate international entrepreneurship lens for new insights into subsidiary initiatives. J. Int. Manag. 2019, 25, 51-65. [CrossRef]

10. Acs, Z.J.; Autio, E.; Szerb, L. National systems of entrepreneurship: Measurement issues and policy implications. Res. Policy 2014, 43, 476-494. [CrossRef]

11. Hong, E.; Lee, I.H.; Sun, L.; Harrison, R. Entrepreneurship across time and space: Empirical evidence from Korea. Small Bus. Econ. 2015, 44, 705-719. [CrossRef]

12. Rezaei-Zadeh, M.; Hogan, M.; O'Reilly, J.; Cunningham, J.; Murphy, E. Core entrepreneurial competencies and their interdependencies: Insights from a study of Irish and Iranian entrepreneurs, university students and academics. Int. Entrep. Manag. J. 2017, 13, 35-73. [CrossRef]

13. Busenitz, L.W.; Plummer, L.A.; Klotz, A.C.; Shahzad, A.; Rhoads, K. Entrepreneurship research (19852-009) and the emergence of opportunities. Entrep. Theory Pract. 2014, 38, 981-1000. [CrossRef]

14. Audretsch, D.B.; Obschonka, M.; Gosling, S.; Potter, J. A new perspective on entrepreneurial regions: Linking cultural identity with latent and manifest entrepreneurship. Small Bus. Econ. 2017, 48, 681-697. [CrossRef]

15. Nazarko, J. Regionalny Foresight Gospodarczy. Scenariusze Rozwoju Innowacyjności Mazowieckich Przedsiębiorstw [Regional business Information Foresight. Scenarios of Innovation-Based Development of Mazovian Enterprises]; Związek Pracodawców Warszawy i Mazowsza: Warsaw, Poland, 2013.

16. Lanahan, L.; Feldman, M.P. Multilevel innovation policy mix: A closer look at state policies that augment the federal SBIR program. Res. Policy 2015, 44, 1387-1402. [CrossRef] 
17. Audretsch, D.B.; Bönte, W.; Mahagaonkar, P. Financial signaling by innovative nascent ventures: The relevance of patents and prototypes. Res. Policy 2012, 41, 1407-1421. [CrossRef]

18. Alvedalen, J.; Boschma, R. A critical review of entrepreneurial ecosystems research: Towards a future research agenda. Eur. Plan. Stud. 2017, 25, 887-903. [CrossRef]

19. Henrekson, M.; Johansson, D. Competencies and Institutions Fostering High-growth Firms. Found. Trends Entrep. 2007, 5, 1-80. [CrossRef]

20. Stam, E. Entrepreneurial Ecosystems and Regional Policy: A Sympathetic Critique. Eur. Plan. Stud. 2015, 23, 1759-1769. [CrossRef]

21. Scott, W.R. Approaching adulthood: The maturing of institutional theory. Theory Soc. 2008, 37, 427-442. [CrossRef]

22. Volery, T.; Mueller, S.; Von Siemens, B. Entrepreneur ambidexterity: A study of entrepreneur behaviors and competencies in growth oriented small and medium-sized enterprises. Int. Small Bus. J. 2015, 33, 109-129. [CrossRef]

23. Fuller, B.; Liu, Y.; Bajaba, S.; Marler, L.E.; Pratt, J. Examining how the personality, self-efficacy, and anticipatory cognitions of potential entrepreneurs shape their entrepreneurial intentions. Pers. Indiv. Differ. 2018, 125, 120-125. [CrossRef]

24. Abdullah, N.; Hadi, N.U.; Dana, L.P. The nexus between entrepreneur skills and successful business: A decompositional analysis. Int. J. Entrep. Small Bus. 2018, 34, 249-265. [CrossRef]

25. Jahanshahi, A.A.; Brem, A.; Shahabinezhad, M. Does thinking style make a difference in environmental perception and orientation? Evidence from entrepreneurs in post-sanction Iran. Sustainability 2018, 10, 1546. [CrossRef]

26. Trettin, L.; Welter, F. Challenges for spatially oriented entrepreneurship research. Entrep. Region. Dev. 2011, 23, 575-602. [CrossRef]

27. Audretsch, D.; Caiazza, R. Technology transfer and entrepreneurship: Cross-national analysis. J. Technol. Transf. 2016, 41, 1247-1259. [CrossRef]

28. Lee, S.H.; Wong, P.K. An exploratory study of technopreneurial intentions: A career anchor perspective. J. Bus. Ventur. 2004, 19, 7-28. [CrossRef]

29. Salhi, B. Impact of personal motivation on the intention and behaviour of social entrepreneurs. J. Entrep. Educ. 2018, 21, 11-15. [CrossRef]

30. Nowak, L.; Thach, L.; Olsen, J.E. Wowing the millennials: Creating brand equity in the wine industry. J. Prod. Brand Manag. 2006, 15, 316-332. [CrossRef]

31. Nabi, G.; Holden, R.; Walmsley, A. Entrepreneurial intentions among students: Towards a re-focused research agenda. J. Small Bus. Enterp. Dev. 2010, 17, 537-551. [CrossRef]

32. Gurtner, S.; Soyez, K. How to catch the Generation Y: Identifying consumers of ecological innovations among youngsters. Technol. Forecast. Soc. 2016, 106, 101-107. [CrossRef]

33. Utami, C.W. Attitude, subjective norms, perceived behavior, entrepreneurship education and self-efficacy toward entrepreneurial intention university student in Indonesia. Eur. Res. Stud. J. 2017, 20, 475-495.

34. Minola, T.; Criaco, G.; Cassia, L. Are youth really different? New beliefs for old practices in entrepreneurship. Int. J. Entrep. Innov. Manag. 2014, 18, 233-259. [CrossRef]

35. Dvouletý, O.; Mühlböck, M.; Warmuth, J.; Kittel, B. Scarred'young entrepreneurs. Exploring young adults' transition from former unemployment to self-employment. J. Youth Stud. 2018, 21, 1159-1181. [CrossRef]

36. Barahona, J.H.; Cruz, N.M.; Escudero, A.I.R. Education and Training as Non-Psychological Characteristics that Influence University Students' Entrepreneurial Behaviour. J. Entrep. Educ. 2006, 9, 99-112.

37. Oftedal, E.M.; Iakovleva, T.A.; Foss, L. University context matter: An institutional perspective on entrepreneurial intentions of students. Educ. Train. 2018, 60, 873-890. [CrossRef]

38. Bae, T.; Qian, S.; Miao, C.; Fiet, J. The relationship between entrepreneurship education and entrepreneurial intentions: A meta-analytic review. Entrep. Theory Pract. 2014, 38, 217-254. [CrossRef]

39. Ferrandiz, J.; Fidel, P.; Conchado, A. Promoting entrepreneurial intention through a higher education program integrated in an entrepreneurship ecosystem. Int. J. Innov. Sci. 2018, 10, 6-21. [CrossRef]

40. Nabi, G.; Walmsley, A.; Liñán, F.; Akhtar, I.; Neame, C. Does entrepreneurship education in the first year of higher education develop entrepreneurial intentions? The role of learning and inspiration. Stud. High. Educ. 2018, 43, 452-467. [CrossRef] 
41. Peng, Z.; Lu, G.; Kang, H. Entrepreneurial intentions and its influencing factors: A survey of the university students in Xi'an China. Creat. Educ. 2012, 3, 95-100. [CrossRef]

42. Dvouletý, A. ; Development of Entrepreneurial Activity in the Czech Republic over the Years 2005-2017. J. Open Innov. Technol. Mark. Complex. 2019, 5, 38. [CrossRef]

43. Bullough, A.; Renko, M.; Myatt, T. Danger zone entrepreneurs: The importance of resilience and self-efficacy for entrepreneurial intentions. Entrep. Theory Pract. 2014, 38, 473-499. [CrossRef]

44. Shapero, A.; Sokol, L. The social dimensions of entrepreneurship. In The Encyclopedia of Entrepreneurship; Kent, C., Sexton, D., Vesper, K.H., Eds.; Prentice-Hall: Englewood Cliffs, NY, USA, 1982; pp. 72-90.

45. Ajzen, I. The theory of planned behavior. Organ. Behav. Hum. Dec. 1991, 50, 179-211. [CrossRef]

46. García, F.J.; Gil, E.; Ruiz, I.; Gutiérrez, D. Entrepreneurial process in peripheral regions: The role of motivation and culture. Eur. Plan. Stud. 2017, 25, 2037-2056. [CrossRef]

47. Hien, D.T.T.; Cho, S.E. The effect of software developers' capabilities on entrepreneurial intention in ICT industries. Int. J. Entrep. 2018, 22, 1-17.

48. Piątek, W.; Kobylińska, U. Oczekiwania pokolenia Y wobec rynku pracy na przykładzie Polski i Hiszpanii. Akad. Zarzadzania 2018, 2, 87-100.

49. Henseler, J.; Ringle, C.M.; Sinkovics, R.R. The use of partial least squares path modeling in international marketing. Adv. Int. Mark. 2009, 20, 277-320. [CrossRef]

50. Chin, W.W.; Dibbern, J. An introduction to a permutation based procedure for multi-group PLS analysis: Results of tests of differences on simulated data and a cross cultural analysis of the sourcing of information system services between Germany and the USA. In Handbook of Partial Least Squares: Concepts, Methods and Applications; Esposito, V., Chin, W.W., Henseler, J., Wang, H., Eds.; Springer: Heidelberg, Germany, 2010; Volume 2, pp. 171-193. [CrossRef]

51. Henseler, J.; Ringle, C.M.; Sarstedt, M. Testing measurement invariance of composites using Partial Least Squares. Int. Mark. Rev. 2016, 33, 405-431. [CrossRef]

52. Moriano, J.A.; Gorgievski, M.; Laguna, M.; Stephan, U.; Zarafshani, K. A Cross-cultural approach to understanding entrepreneurial intention. J. Career Dev. 2011, 39, 162-185. [CrossRef]

53. Esfandiar, K.; Sharifi-Tehrani, M.; Pratt, S.; Altinay, L. Understanding entrepreneurial intentions: A developed integrated structural model approach. J. Bus. Res. 2019, 94, 172-182. [CrossRef]

54. Rauch, A.; Frese, M. Let's put the person back into entrepreneurship research: A meta-analysis on the relationship between business owners' personality traits, business creation, and success. Eur. J. Work Organ. Psy. 2007, 16, 353-385. [CrossRef]

55. Wasowska, A. Perception of export barriers at different stages of the internationalisation process, evidence from European SMEs. J. Entrep. Manage. Innov. 2016, 12, 29-50. [CrossRef]

56. Karimi, S.; Biemans, H.J.A.; Lans, T.; Chizari, M.; Mulder, M. The impact of entrepreneurship education: A study of Iranian students' entrepreneurial intentions and opportunity identification. J. Small Bus. Manag. 2016, 54, 187-209. [CrossRef]

57. Turton, N.; Herrington, M. Global Entrepreneurship Monitor South. Africa; UCT Graduate School of Business: Cape Town, South Africa, 2012.

58. Hornsby, J.; Peña-Legazkue, I.; Guerrero, M. Guest editorial: The role of corporate entrepreneurship in the current organizational and economic landscape. Int Entrep Manag. J. 2013, 9, 295-305. [CrossRef]

59. Guerrero, M.; Peña-Legazkue, I. The effect of intrapreneurial experience on corporate venturing: Evidence from developed economies. Int Entrep Manag. J. 2013, 9, 397-416. [CrossRef]

60. Shirokova, G.; Osiyevskyy, O.; Bogatyreva, K. Exploring the intention-behavior link in student entrepreneurship: Moderating effects of individual and environmental characteristics. Eur. Manag. J. 2016, 34, 386-399. [CrossRef]

61. Liñán, F.; Fayolle, A. A systematic literature review on entrepreneurial intentions: Citation, thematic analyses, and research agenda. Int. Entrep. Manag. J. 2015, 11, 907-933. [CrossRef]

62. Kautonen, T.; van Gelderen, M.; Fink, M. Robustness of the theory of planned behaviour in predicting entrepreneurial intentions and action. Enterp. Theory Pract. 2015, 39, 655-674. [CrossRef]

63. Soomro, B.A.; Shah, N. Developing attitudes and intentions among potential entrepreneurs. J. Enterp. Inform. Manag. 2015, 28, 304-322. [CrossRef]

64. Thompson, E.R. Individual Entrepreneurial Intent: Construct Clarification and Development of an Internationally Reliable Metric. Entrepr. Theory Pract. 2009, 33, 669-694. [CrossRef] 
65. Liguori, E.; Winkler, C.; Winkel, D.; Marvel, M.R.; Keels, J.K.; van Gelderen, M.; Noyes, E. The entrepreneurship education imperative: Introducing EE\&P. Entrep. Educ. Ped. 2018, 1, 5-7. [CrossRef]

66. Bird, B. Implementing Entrepreneurial Ideas: The Case for Intention. Acad. Manag. Rev. 1988, 13, 442-453. [CrossRef]

67. Schlaegel, C.; Koenig, M. Determinants of entrepreneurial intent: A meta-analytic test and integration of competing models. Entrep. Theory Pract. 2014, 38, 291-332. [CrossRef]

68. Elfving, J.; Brännback, M.; Carsrud, A. Revisiting a contextual model of entrepreneurial intentions. In Revisiting the Entrepreneurial Mind; Brännback, M., Carsrud, A.L., Eds.; Springer International Publishing: Cham, Switzerland, 2017; pp. 83-90. [CrossRef]

69. Krueger, N.F.; Reilly, M.D.; Carsrud, A.L. Competing models of entrepreneurial intentions. J. Bus. Ventur. 2000, 15, 411-432. [CrossRef]

70. Ajzen, I.; Fishbein, M. The influence of attitudes on behaviour. In The Handbook of Attitudes; Albarracín, D., Johnson, B.T., Zanna, M.P., Eds.; Erlbaum: Mahwah, NY, USA, 2005; pp. 173-221.

71. Ajzen, I.; Cote, N.G. Attitudes and the prediction of behaviour. In Attitudes and Attitude Change; Crano, W.D., Prislin, R., Eds.; Psychology Press: New York, NY, USA, 2008; pp. 289-311.

72. Liñán, F.; Chen, Y. Development and cross-cultural application of a specific instrument to measure entrepreneurial intentions. Entrep. Theory Pract. 2009, 33, 593-617. [CrossRef]

73. Van Gelderen, M.; Kautonen, T.; Wincent, J.; Biniari, M. Implementation intentions in the entrepreneurial process: Concept, empirical findings, and research agenda. Small Bus. Econ. 2017, 51, 923-941. [CrossRef]

74. Vuorio, A.M.; Puumalainen, K.; Fellnhofer, K. Drivers of entrepreneurial intentions in sustainable entrepreneurship. Int. J. Entrep. Behav. Res. 2018, 24, 359-381. [CrossRef]

75. Fitzsimmons, J.R.; Douglas, E.J. Interaction between feasibility and desirability in the formation of entrepreneurial intentions. J. Bus. Ventur. 2011, 26, 431-440. [CrossRef]

76. Hui, C.; Kuen, T.; Chen, P. The entrepreneurial process: An integrated model. Int. Entrep. Manag. J. 2014, 10, 727-745. [CrossRef]

77. Lanero, A.; Vázquez, J.L.; Muñoz, A. A social cognitive model of entrepreneurial intentions in university students. An. Psicol. 2015, 31, 243-259. [CrossRef]

78. Grégoire, D.A.; Cornelissen, J.P.; Dimov, D.; Van Burg, E. The mind in the middle: Taking stock of affect and cognition research in entrepreneurship. Int. J. Manag. Rev. 2015, 17, 125-142. [CrossRef]

79. Ferreira, J.J.; Raposo, M.L.; Rodrigues, R.G.; Dinis, A.; Paço, A.D. A model of entrepreneurial intention: An application of the psychological and behavioral approaches. J. Small Bus. Enterp. Dev. 2012, 19, 424-440. [CrossRef]

80. Wilson, F.; Kickul, J.; Marlino, D. Gender, entrepreneurial self-efficacy, and entrepreneurial career intentions: Implications for entrepreneurship education. Entrep. Theory Pract. 2007, 31, 387-406. [CrossRef]

81. Carr, J.C.; Sequeira, J.M. Prior family business exposure as international influence and entrepreneurial intent: A theory of planned behavior approach. J. Bus. Res. 2007, 60, 1090-1098. [CrossRef]

82. Liñán, F.; Santos, F.J. La influencia del capital social sobre los empresarios potenciales. Estud. Econ. Appl. 2006, 24, 459-489.

83. Segal, G.; Borgia, D.; Schoenfeld, J. The motivation to become an entrepreneur. Int. J. Entrep. Behav. Res. 2005, 11, 42-57. [CrossRef]

84. Pittaway, L.; Cope, J. Entrepreneurship education: A systematic review of the evidence. Int. Small Bus. J. 2007, 25, 479-510. [CrossRef]

85. Engle, R.L.; Dimitriadi, N.; Gavidia, J.V.; Schlaegel, C.; Delanoe, S.; Alvarado, I.; He, X.; Buame, S.; Wolff, B. Entrepreneurial Intent: A Twelve-Country Evaluation of Ajzen's Model of Planned Behavior. Int. J. Entrep. Behav. Res. 2010, 16, 35-57. [CrossRef]

86. Koe, W.; Majid, I. A model for predicting intention towards sustainable entrepreneurship. Int. J. Inform. Bus. Manag. 2004, 6, 256-269.

87. Koe, W.; Omar, R.; Majid, I. Factors associated with propensity for sustainable entrepreneurship. Procedia Soc. Behav. Sci. 2014, 130, 65-74. [CrossRef]

88. Haydam, N.; Purcarea, T.; Edu, T.; Negricea, I.C. Explaining satisfaction at a foreign tourism destination-an intra-generational approach. Evidence within Generation Y from South Africa and Romania. Amfiteatru Econ. J. 2017, 45, 528-543. 
89. Duffett, R.; Petroșanu, D.M.; Negricea, I.C.; Edu, T. Effect of YouTube Marketing Communication on Converting Brand Liking into Preference among Millennials Regarding Brands in General and Sustainable Offers in Particular. Evidence from South Africa and Romania. Sustainability 2019, 11, 604. [CrossRef]

90. Laspita, S.; Breugst, N.; Heblich, S.; Patzelt, H. Intergenerational transmission of entrepreneurial intentions. J. Bus. Ventur. 2012, 27, 414-435. [CrossRef]

91. Kautonen, T.; Van Gelderen, M.; Tornikoski, E.T. Predicting entrepreneurial behaviour: A test of the theory of planned behavior. Appl. Econ. 2013, 45, 697-707. [CrossRef]

92. Prabhu, V.P.; McGuire, S.J.; Drost, E.A.; Kwong, K.K. Proactive personality and entrepreneurial intent. Int. J. Entrep. Behav. Res. 2012, 18, 559-586. [CrossRef]

93. Smallbone, D.; Welter, F. Cross border entrepreneurship. Entrep. Region. Dev. 2012, 24, 95-104. [CrossRef]

94. Engle, R.L.; Schlaegel, C.; Dimitriadi, N. Institutions and entrepreneurial intent: A cross-country study. J. Dev. Entrep. 2011, 16, 227-250. [CrossRef]

95. Nga, K.H.; Shamuganathan, G. The influence of personality traits and demographic factors on social entrepreneurship start up intentions. J. Bus. Ethics 2010, 95, 259-282. [CrossRef]

96. Zellweger, T.; Sieger, P.; Halter, F. Should I stay or should I go? Career choice intentions of students with family business background. J. Bus. Ventur. 2011, 26, 521-536. [CrossRef]

97. Goethner, M.; Obschonka, M.; Silbereisen, R.K.; Cantner, U. Scientists' transition to academic entrepreneurship: Economic and psychological determinants. J. Econ. Psychol. 2012, 33, 628-641. [CrossRef]

98. Martin, B.C.; McNally, J.J.; Kay, M.J. Examining the formation of human capital in entrepreneurship: A meta-analysis of entrepreneurship education outcomes. J. Bus. Ventur. 2013, 28, 211-224. [CrossRef]

99. Halberstadt, J.; Schank, C.; Euler, M.; Harms, R. Learning sustainability entrepreneurship by doing: Providing a lecturer-oriented service learning framework. Sustainability 2019, 11, 1217. [CrossRef]

100. Tarnanidis, T.; Papathanasiou, J.; Subeniotis, D. How far the TBL concept of sustainable entrepreneurship extends beyond the various sustainability regulations: Can Greek food manufacturing enterprises sustain their hybrid nature over time? J. Bus. Ethics 2019, 154, 829-846. [CrossRef]

101. Lheureux, F.; Auzoult, L. Me, an entrepreneur? Entrepreneurial identity, outgroup social identification, attitudes and intentions towards business creation. Rev. Psicol. Soc. 2017, 32, 246-275. [CrossRef]

102. Burrus, J.; Moore, R. The incremental validity of beliefs and attitudes for predicting mathematics achievement. Learn. Individ. Differ. 2016, 50, 246-251. [CrossRef]

103. Cote, J.E.; Levine, C.G. Identity Formation, Agency, and culture: A Social Psychological Synthesis; Lawrence Erlbaum Associates: Mahwah, NY, USA, 2002.

104. Bamberg, S.; Schmidt, P. Incentives, morality, or habit? Predicting students' car use for university routes with the models of Ajzen, Schwartz, and Triandis. Environ. Behav. 2003, 35, 264-285. [CrossRef]

105. Gagnon, M.P.; Sánchez, E.; Pons, J.M. From recommendation to action: Psychosocial factors influencing physician intention to use Health Technology Assessment (HTA) recommendations. Implement. Sci. 2006, 1, 1-11. [CrossRef]

106. Fayolle, A.; Basso, O.; Tornikoski, E. Entrepreneurial commitment and new venture creation: A conceptual exploration. In Handbook of Research on New Venture Creation; Hindle, K., Klyver, K., Eds.; Edward Elgar Publishing Limited: Cheltenham, UK, 2011; pp. 160-182. [CrossRef]

107. Budd, R.J.; Spencer, C.P. Exploring the role of personal normative beliefs in the theory of reasoned action: The problem of discriminating between alternative path models. Eur. J. Soc. Psychol. 1985, 15, $299-313$. [CrossRef]

108. Botsaris, C.; Vamvaka, V. Attitude toward entrepreneurship: Structure, prediction from behavioral beliefs, and relation to entrepreneurial intention. J. Knowl. Econ. 2016, 7, 433-460. [CrossRef]

109. Nordlund, A.M.; Garvill, J. Effects of values, problem awareness, and personal norm on willingness to reduce personal car use. J. Environ. Psychol. 2003, 23, 339-347. [CrossRef]

110. Schultz, W.P.; Khazian, A.M.; Zaleski, A.C. Using normative social influence to promote conservation among hotel guests. Soc. Influ. 2008, 3, 4-23. [CrossRef]

111. Hayton, J.C.; Gerard, G.; Shaker, A.Z. National culture and entrepreneurship: A review of behavioral research. Entrep. Theory Pract. 2002, 26, 33-52. [CrossRef]

112. Vohs, K.D.; Baumeister, R.F.; Schmeichel, B.J. Motivation, personal beliefs, and limited resources all contribute to self-control. J. Exp. Soc. Psychol. 2012, 48, 943-947. [CrossRef] 
113. Tomczyk, D.; Lee, J.; Winslow, E. Entrepreneurs' personal values, compensation, and high growth firm performance. J. Small Bus. Manag. 2013, 51, 66-82. [CrossRef]

114. Caggiano, V.; Akanazu, H.; Furfari, A.; Hageman, A. Entrepreneurship education: A global evaluation of entrepreneurial attitudes and values (a transcultural study). J. Educ. Cult. Psych. Stud. 2016, 14, 57-81. [CrossRef]

115. Jahanshahi, A.A.; Brem, A.; Bhattacharjee, A. Who takes more sustainability-oriented entrepreneurial actions? The role of entrepreneurs' values, beliefs and orientations. Sustainability 2017, 9, 1636. [CrossRef]

116. Wyrwich, M. Entrepreneurship and the intergenerational transmission of values. Small Bus. Econ. 2015, 45, 191-213. [CrossRef]

117. Poblete, C. Growth expectations through innovative entrepreneurship: The role of subjective values and duration of entrepreneurial experience. Int. J. Entrep. Behav. Res. 2018, 24, 191-213. [CrossRef]

118. Fornara, F.; Pattitoni, P.; Mura, M.; Strazzera, E. Predicting intention to improve household energy efficiency: The role of value-belief-norm theory, normative and informational influence, and specific attitude. J. Environ. Psychol. 2016, 45, 1-10. [CrossRef]

119. Gird, A.; Bagraim, J.J. The theory of planned behaviour as predictor of entrepreneurial intent amongst final-year university students. S. Afr. J. Psychol. 2008, 38, 711-724. [CrossRef]

120. Cho, H.; Lee, J. The influence of self-efficacy, subjective norms, and risk perception on behavioral intentions related to the H1N1 flu pandemic: A comparison between Korea and the US Hichang. Asian J. Soc. Psychol. 2015, 18, 311-324. [CrossRef]

121. Skinner, H.; Sarpong, D.; White, G. Meeting the needs of the Millennials and Generation Z: Gamification in tourism through geocaching. J. Tour. Fut. 2018, 4, 93-104. [CrossRef]

122. Sridhar, S.; Srinivasan, R. Social influence effects in online product ratings. J. Mark. 2012, 75, 70-88. [CrossRef]

123. Wu, J.; Neck, C.P.; Houghton, J.D.; Pozzuto, A. Family satisfaction and entrepreneurship among Chinese women: The moderating role of self-efficacy. Int. J. Bus. Global. 2013, 11, 291-309. [CrossRef]

124. Manan, H.A. The hierarchical influence of personal values on attitudes toward food and food choices. Procedia Econ. Fin. 2016, 37, 439-446. [CrossRef]

125. Vincent, T.N.; Selvarani, D.C. Personal values approach for a better understanding of consumer behavior. Int. J. Innov. Res. Dev. 2013, 2, 509-517.

126. Cai, Y.; Shannon, R. Personal values and mall shopping behavior: The mediating role of attitude and intention among Chinese and Thai consumers. Int. J. Retail. Distrib. Manag. 2012, 40, 37-47. [CrossRef]

127. Fischer, R.; Schwartz, S.H. Whence differences in value priorities? Individual, cultural, or artifactual sources. J. Cross Cult. Psychol. 2011, 42, 1127-1144. [CrossRef]

128. Schwartz, S.H. Value orientations: Measurement, antecedents and consequences across nations. In Measuring Attitudes Cross-Nationally_Lessons from the European Social Survey; Jowell, R., Roberts, C., Fitzgerald, R., Eva, G., Eds.; Sage Publications: London, UK, 2007; pp. 169-203. [CrossRef]

129. Vauclair, C.M.; Fischer, R. Do cultural values predict individuals' moral attitudes? A cross-cultural multilevel approach. Eur. J. Soc. Psychol. 2011, 41, 645-657. [CrossRef]

130. Chen, M.H.; Chang, Y.Y.; Wang, H.Y.; Chen, M.H. Understanding creative entrepreneurs' intention to quit: The role of entrepreneurial motivation, creativity, and opportunity. Entrep. Res. J. 2017, 7, 1-15. [CrossRef]

131. Mahto, R.V.; McDowell, W.C. Entrepreneurial motivation: A non-entrepreneur's journey to become an entrepreneur. Int. Entrep. Manag. J. 2018, 14, 513-526. [CrossRef]

132. Solesvik, M.Z. Entrepreneurial motivations and intentions: Investigating the role of education major. Educ. Train. 2013, 55, 253-271. [CrossRef]

133. Zimmerman, M.A.; Chu, H.N. Motivation, success, and problems of entrepreneurs in Venezuela. J. Manage. Policy Pract. 2013, 14, 76-90.

134. Fatoki, O. Student entrepreneurs on university campus in South Africa: Motivations, challenges and entrepreneurial intention. Mediterr. J. Soc. Sci. 2014, 5, 100-107. [CrossRef]

135. Hechavarria, D.M.; Reynolds, P.D. Cultural norms \& business start-ups: The impact of national values on opportunity and necessity entrepreneurs. Int. Entrep. Manag. J. 2009, 5, 417-437. [CrossRef]

136. Kirkwood, J. Motivational factors in a push-pull theory of entrepreneurship. Gend. Manage. Int. J. 2009, 25, 346-364. [CrossRef]

137. Edelman, L.F.; Brush, C.G.; Manolova, T.S.; Greene, P. Start-up motivations and growth intentions of minority nascent entrepreneurs. J. Small Bus. Manag. 2010, 48, 174-196. [CrossRef] 
138. Bandura, A. Social cognitive theory: An agentic perspective. Ann. Rev. Psychol. 2001, 52, 1-26. [CrossRef]

139. Margolis, H.; McCabe, P. Improving self-efficacy and motivation: What to do, what to say. Interv. Sch. Clin. 2006, 41, 218-227. [CrossRef]

140. Fayolle, A.; Liñán, F.; Moriano, J. Beyond entrepreneurial intentions: Values and motivations in entrepreneurship. Int. Entrep. Manag. J. 2014, 10, 679-689. [CrossRef]

141. Cardon, M.S.; Kirk, C.P. Entrepreneurial passion as mediator of the self-efficacy to persistence relationship. Entrep. Theory Pract. 2015, 39, 1027-1050. [CrossRef]

142. Zhao, H.; Seibert, S.E.; Hills, G.E. The mediating role of self-efficacy in the development of entrepreneurial intentions. J. Appl. Psychol. 2005, 90, 1265-1272. [CrossRef] [PubMed]

143. Pihie, Z.A.L.; Bagheri, A. Self-efficacy and entrepreneurial intention: The mediation effect of self-regulation. Vocat. Learn. 2013, 6, 385-401. [CrossRef]

144. Kim, H.J.; Jang, J.M. The easier the better: How processing fluency influences self-efficacy and behavioral intention in pro-social campaign advertising. Sustainability 2018, 10, 4777. [CrossRef]

145. Mishra, S.; Fiddick, L. Beyond gains and losses: The effect of need on risky choice in framed decisions. J. Person. Soc. Psychol. 2012, 102, 1136-1142. [CrossRef]

146. Pijnenburg, K.; Kholodilin, K.A. Do regions with entrepreneurial neighbours perform better? A spatial econometric approach for German regions. Reg. Stud. 2014, 48, 866-882. [CrossRef]

147. Charters, S.; Velikova, N.; Ritchie, C.; Fountain, J.; Tach, L.; Dodd, T.; Fish, N.; Herbst, F.; Terblanche, N. Generation $Y$ and sparkling wines: A cross-cultural perspective. Int. J. Wine Bus. Res. 2011, 3, 161-175. [CrossRef]

148. Kokocińska, M.; Nowak, H. Edukacja w Zakresie Przedsiębiorczości. Doświadczenia Polski i Hiszpanii [Entrepreneurship Education. Experience of Poland and Spain]; Difin: Warsaw, Poland, 2014.

149. Kobylińska, U.; Biglieri, J.V. Public Sector Innovativeness in Poland and in Spain-Comparative Analysis. Int. J. Contemp. Manag. 2015, 14, 7-22.

150. Hair, J.F.; Ringle, C.M.; Sarstedt, M. PLS-SEM: Indeed a silver bullet. J. Mark. Theory Pract. 2011, 19, $139-152$. [CrossRef]

151. Hair, J.F.; Sarstedt, M.; Pieper, T.M.; Ringle, C.M. The use of partial least squares structural equation modeling in strategic management research: A review of past practices and recommendations for future applications. Long Range Plann 2012, 45, 320-340. [CrossRef]

152. Hair, J.F.; Black, W.C.; Babin, B.J.; Anderson, R.E. Multivariate Data Analysis; Pearson Education Limited: Halow, UK, 2014.

153. Rasoolimanesh, S.M.; Roldán, J.L.; Jaafar, M.; Ramayah, T. Factors influencing residents' perceptions toward tourism development differences across rural and urban world heritage sites. J. Travel Res. 2017, 56, 760-775. [CrossRef]

154. Ringle, C.; Wende, S.; Becker, J. SmartPLS 3 (Version 3.2.3); SmartPLS GmbH: Boenningstedt, Germany, 2015.

155. Sarstedt, M.; Henseler, J.; Ringle, C. Multigroup analysis in Partial Least Squares (PLS) path modeling: Alternative methods and empirical results. Adv. Int. Mark. 2011, 22, 195-218. [CrossRef]

156. Hair, J.F.; Sarstedt, M.; Hopkins, L.; Kuppelwieser, V. Partial least squares structural equation modeling (PLS-SEM): An emerging tool in business research. Eur. Bus. Rev. 2014, 26, 106-121. [CrossRef]

157. Hair, J.F.; Hult, G.T.M.; Ringle, C.M.; Sarstedt, M. A Primer on Partial Least Squares Structural Equation Modeling (PLS-SEM); Sage: Thousand Oaks, CA, USA, 2014.

158. Bruwer, J.; Saliba, A.; Miller, B. Consumer behavior and sensory preference differences: Implications for wine product marketing. J. Consum. Mark. 2011, 28, 5-18. [CrossRef]

159. Cohen, J. Statistical Power Analysis for the Behavioral Sciences, 2nd ed.; Erlbaum: Hillsdale, NY, USA, 1988.

160. Faul, F.; Erdfelder, E.; Buchner, A.; Lang, A.G. Statistical power analyses using G*Power 3.1: Tests for correlation and regression analyses. Behav. Res. Method. 2009, 41, 1149-1160. [CrossRef] [PubMed]

161. Taylor, C.A.; Hewitt, A.D. A methodology for assessing sample representativeness. Environ. Forensics 2015, 6, 71-75. [CrossRef]

162. Ayadi, S.; Ghorbel, S.Z. Relevance of the Mann Whitney Wilcoxon test in the survival analysis of newly established companies in Tunisia (Case of the sfax region). J. Glob. Entrep. Res. 2018, 8, 1-20. [CrossRef]

163. Reinartz, W.; Haenlein, M.; Henseler, J. An empirical comparison of the efficacy of covariance-based and variance-based SEM. Int. J. Res. Mark. 2009, 6, 332-344. [CrossRef] 
164. Hair, J.F.; Celsi, M.; Money, A.; Samouel, P.; Page, M. The Essentials of Business Research Methods; Routledge: New York, NY, USA, 2015.

165. Bergkvist, L.; Rossiter, J. The predictive validity of multiple-item versus single-item measures of the same constructs. J. Mark. Res. 2007, 44, 175-184. [CrossRef]

166. Fang, W.T.; Ng, E.; Wang, C.M.; Hsu, M.L. Normative beliefs, attitudes, and social norms: People reduce waste as an index of social relationships when spending leisure time. Sustainability 2017, 9, 1696. [CrossRef]

167. Gächter, S.; Renner, E. Leaders as role models and 'belief managers' in social dilemmas. J. Econ. Behav. Organ. 2018, 154, 321-334. [CrossRef]

168. Lehto, X.Y.; O'Leary, J.T.; Morrison, A.M. The effect of prior experience on vacation behavior. Ann. Tour. Res. 2004, 31, 801-818. [CrossRef]

169. Kline, R.B. Principles and Practice of Structural Equation Modeling, 3rd ed.; Guilford Press: New York, NY, USA, 2011.

170. Yong, A.G.; Pearce, S. A beginner's guide to factor analysis: Focusing on exploratory factor analysis. Quant. Method. Psychol. 2013, 9, 79-94. [CrossRef]

171. Hair, J.F.; Ringle, C.M.; Sarstedt, M. A Primer on Partial Least Squares Structural Equation Modelling (PLS-SEM); California SAGE Publications, Inc.: Thousand Oaks, CA, USA, 2013.

172. Fornell, C.; Larcker, D. Evaluating structural equation models with unobservable variables and measurement error. J. Mark. Res. 1981, 18, 39-50. [CrossRef]

173. Chin, W.W. How to write up and report PLS analyses. In Handbook of Partial Least Squares: Concepts, Methods and Applications; Esposito, V., Chin, W.W., Henseler, J., Wang, H., Eds.; Springer: Heidelberg, Berlín, 2010; pp. 655-690. [CrossRef]

174. Chin, W. Issues and opinion on structural equation modeling. MIS Q. 1998, 22, 7-16.

175. Barroso, A.; González, O.R.; Sanguino, R.; Buenadicha, M. Analysis and evaluation of the largest 500 family firms'websites through PLS-SEM Technique. Sustainability 2018, 10, 557. [CrossRef]

176. Sarstedt, M.; Ringle, C.M.; Smith, D.; Reams, R.; Hair, J.F. Partial least squares structural equation modeling (PLS-SEM): A useful tool for family business researchers. J. Fam. Bus. Strateg. 2014, 5, 105-115. [CrossRef]

177. Riquel, F.J.; Vargas, A. Las presiones institucionales del entorno medioambiental: Aplicación a los campos de golf. Rev. Eur. Dire. Econ. Emp. 2013, 22, 29-38. [CrossRef]

178. Wetzels, M.; Odekerken-Schroeder, G.; Van Oppen, C. Using PLS path modelling for assessing hierarchical construct models: Guidelines and empirical illustration. Mis Quart. 2009, 33, 177-195. [CrossRef]

179. Hair, J.F.; Sarstedt, M.; Ringle, C.M.; Gudergan, S.P. Advanced Issues in Partial Least Squares Structural Equations Modeling (PLS-SEM); Sage: Thousand Oaks, CA, USA, 2018.

180. Schlagel, C.; Sarstedt, M. Assessing the measurement invariance of the four-dimensional cultural intelligence scale across countries: A composite model approach. Eur. Manage. J. 2016, 34, 633-649. [CrossRef]

181. Dijkstra, T.K.; Henseler, J. Linear indices in nonlinear structural equation models: Best fitting proper indices and other composites. Qual. Quant. 2011, 45, 1505-1518. [CrossRef]

182. Martínez González, J.A.; Kobylińska, U. Influence of personal variables on entrepreneurial intention: A comparative study between Poland and Spain. Eng. Manag. Prod. Serv. 2019, 11, 68-79. [CrossRef]

183. Hall, J.K.; Daneke, G.A.; Lenox, M.J. Sustainable development and entrepreneurship: Past contributions and future directions. J. Bus. Ventur. 2010, 25, 439-448. [CrossRef]

184. Patzelt, H.; Shepherd, D.A. Recognizing Opportunities for Sustainable Development. Entrep. Theory Pract. 2011, 35, 631-652. [CrossRef]

185. Tilley, F.; Parrish, B.D. From poles to wholes: Facilitating an integrated approach to sustainable entrepreneurship. World Rev. Entrep. Manag. Sustain. Dev. 2006, 2, 281-294. [CrossRef]

186. Guerrero, M.; Urbano, D.; Fayolle, A. Entrepreneurial activity and regional competitiveness: Evidence from European entrepreneurial universities. J. Technol. Transfer. 2016, 41, 105-131. [CrossRef]

187. Schwarz, E.J.; Wdowiak, M.A.; Almer-Jarz, D.A.; Breitenecker, R.J. The effects of attitudes and perceived environment conditions on students' entrepreneurial intent: An Austrian perspective. Educ. Train. 2009, 51, 272-291. [CrossRef]

188. Passaro, R.; Quinto, I.; Thomas, A. The impact of higher education on entrepreneurial intention and human capital. J. Intellect. Cap. 2018, 19, 135-156. [CrossRef]

189. Shepherd, D.A.; Patzelt, H. The new field of sustainable entrepreneurship: Studying entrepreneurial action linking "what is to be sustained" with "what is to be developed". Entrep. Theory Pract. 2011, 35, 137-163. [CrossRef] 
190. Bischoff, K.; Volkmann, C.K. Stakeholder support for sustainable entrepreneurship-a framework of sustainable entrepreneurial ecosystems. Int. J. Entrep. Ventur. 2018, 10, 172-201. [CrossRef]

191. Meek, W.R.; Pacheco, D.F.; York, J.G. The impact of social norms on entrepreneurial action: Evidence from the environmental entrepreneurship context. J. Bus. Ventur. 2010, 25, 493-509. [CrossRef]

192. Simatupang, T.M.; Schwab, A.; Lantu, D.C. Building sustainable entrepreneurship ecosystems, Introduction. Int. J. Entrep. Small Bus. 2015, 26, 389-398. [CrossRef]

193. Ejdys, J.; Halicka, K. Sustainable adaptation of new technology—the case of humanoids used for the care of older adults. Sustainability 2018, 10, 3770. [CrossRef]

194. Popper, R.; Popper, M.; Velasco, G. Towards a more responsible sustainable innovation assessment and management culture in Europe. Eng. Manag. Prod. Serv. 2017, 9, 7-20. [CrossRef]

195. Muñoz, P.; Cohen, B. Entrepreneurial Narratives in Sustainable Venturing: Beyond People, Profit, and Planet. J. Small Bus. Manag. 2018, 56, 154-176. [CrossRef]

196. Bank, N.; Fichter, K.; Klofsten, M. Sustainability-profiled incubators and securing the inflow of tenants-The case of Green Garage Berlin. J. Clean. Prod. 2017, 157, 76-83. [CrossRef]

197. Ejdys, J.; Matuszak-Flejszman, J. New management systems as an instrument of implementation sustainable development concept at organizational level. Technol. Econ. Dev. Econ. 2010, 16, 202-218. [CrossRef]

198. Nazarko, L. Responsible Research and Innovation-A New Paradigm of Technology Management. In Proceedings of the 9th International Scientific Conference "Business and Management 2016", Vilnius, Lithuania, 12-13 May 2016. [CrossRef]

(C) 2019 by the authors. Licensee MDPI, Basel, Switzerland. This article is an open access article distributed under the terms and conditions of the Creative Commons Attribution (CC BY) license (http://creativecommons.org/licenses/by/4.0/). 